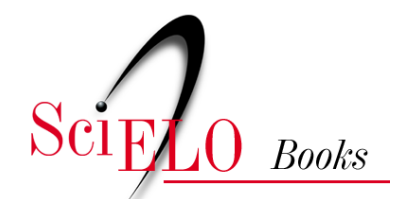

\title{
Capítulo 2 - 0 harém nas narrativas de viagem ao Levante no século XVIII
}

\author{
Marina de Oliveira Soares
}

\section{SciELO Books / SciELO Livros / SciELO Libros}

SOARES, M. O. O harém nas narrativas de viagem ao Levante no século XVIII. In: $O$ harém ao rés do chão: imaginário europeu e representações médicas sobre o lugar-segredo, 1599-1791 [online]. São Bernardo do Campo, SP: Editora UFABC, 2017, pp. 109-189. ISBN 978-85-68576-81-6. https://doi.org/10.7476/9788568576816.0004.

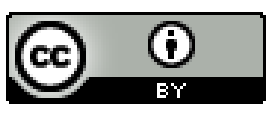

All the contents of this work, except where otherwise noted, is licensed under a Creative Commons Attribution 4.0 International license.

Todo o conteúdo deste trabalho, exceto quando houver ressalva, é publicado sob a licença Creative Commons Atribição 4.0.

Todo el contenido de esta obra, excepto donde se indique lo contrario, está bajo licencia de la licencia Creative Commons Reconocimento 4.0. 


\section{O harém nas narrativas de víagem ao Levante no século XVIII}

\subsection{Harém e serralho nos dícionáríos europeus}

Como pudemos notar no Capítulo 1, as definições sobre o serralho - termo usado pelos autores de viagem e também pelos dicionaristas com mais frequência do que harém - possuíam uma indicação geral e outra particular. $\mathrm{O}$ serralho era tomado como sinônimo de palácio e, de forma específica, como o palácio dos governantes orientais. Afora essas duas acepções, foi possível encontrar em uma menor parte desses autores a referência sexual atrelada ao significado do termo. Esta mesma postura pode ser verificada nos dicionários europeus elaborados ao longo do século XVIII.

Após a consulta a um conjunto de dicionários alemães, franceses, ingleses e a um dicionário espanhol - todos produzidos durante o século XVIII -, pode-se afirmar que o padrão 
conceitual usado pelos viajantes também era comum entre os organizadores de tais dicionários. Isso significa que se encontra entre esses autores a utilização do termo serralho - mais do que o emprego da palavra harém -, sendo as explicações fornecidas ao leitor amparadas no binômio palácio-senhor turco/islâmico. Além disso, em dois dicionários alemães e em um dicionário francês, serralho foi definido como uma habitação ampla. Outra semelhança entre esses três dicionários era o lembrete de que a palavra serralho tinha origem na língua persa.

O Novo Dicionário da Academia Francesa, de 1718, não apresentava o termo "harém". Ali havia apenas a palavra serralho que era definida como o palácio habitado pelos "príncipes do Oriente". Ainda nessa entrada, informava-se aos leitores - como na edição de 1694 - que o serralho era conceituado de forma inadequada como uma casa em que alguém mantinha mulheres para a lascívia (NOUVEAU DICTIONNAIRE DE L'ACADÉMIE FRANÇOISE, 1718, p. 587-588). A mesma apresentação sobre o serralho era feita na edição de 1740, acrescentando-se, contudo, que se tratava da parte do palácio onde as mulheres eram fechadas (p. 661). A palavra serralho teve a grafia alterada na edição de 1762 , de serrail para sérail. Além disso, neste ano, inseria-se a informação de que o nome do local onde as mulheres eram fechadas era harém e não serralho. A edição de 1798 ainda não trazia entrada para harém. No dicionário compilado pelo filólogo inglês Nathan [ou Nathaniel] Bailey (m. 1742) - com data registrada em 1675, mas possivelmente publicado em 1775 -, aparecia apenas o termo serralho [Seraglio] cujo significado era "palácio do Grão-Senhor, e de outros Príncipes 
Orientais, onde as suas concubinas são mantidas" (1675, [s. p.]).

No Novo dicionário francês - uma variação do $D i$ cionário da Academia Francesa, em edição de 1792 - fazia-se uma ressalva em relação ao sentido impróprio tomado pelo termo serralho. A afirmação encontrada era de que se dizia comumente, "mas inapropriadamente", que o serralho era a "parte do Palácio do Grão-Senhor onde as mulheres são fechadas". O texto prosseguia, alegando-se que o nome verdadeiro desse lugar era harém (NOUVEAU DICTIONNAIRE FRANÇOIS, 1792, Tomo II, p. 510). Logo em seguida, alertava-se para outro sentido inadequado do termo, ou seja, aquele que afirmava ser o serralho um local para se manterem mulheres com vista ao prazer. A entrada para o termo harém, entretanto, ainda era ausente neste dicionário.

Poucos dicionários consultados salientavam o caráter luxurioso das habitações femininas dentro do palácio. Essa associação pôde ser encontrada no Dicionário da Língua Inglesa, de Samuel Johnson, e no Dicionário Universal. $\mathrm{Na}$ terceira edição do dicionário de Johnson, o autor definia serralho como "uma casa para manter mulheres com vista ao deboche” (1768, [s. p.]). Já no Dicionário Universal, lia-se que, "por comparação", o serralho era o lugar de "prazer e deboche, as casas onde alguns grandes Senhores mantinham mulheres para se divertir" (ANTOINE, 1738-1742, p. 1964-1965).

Havia, de outro modo, uma ligação corrente entre serralho e sexualidade. No Lingua Britannica Reformata, de Benjamin Martin (1749), a entrada para serralho apresentava duas definições: "1. palácio de um príncipe do 
leste; 2. um lugar para manter concubinas". Não existia entrada para harém nesse dicionário (p. 907). No Diccionario de la lengua castellana compuesto por la Real Academia Española de 1783, definia-se este espaço como "a casa ou o palácio real do Grande Turco". Tratava-se da "residência dos imperadores turcos" na qual "[os governantes] têm as suas mulheres e concubinas" (REAL ACADEMIA ESPAÑOLA 1783, p. 852). A referência às concubinas aparecia ainda no Dicionário Universal. Em sua terceira definição de serralho, informava-se que a palavra era empregada também como sinônima "das mulheres e das concubinas dos Príncipes do Oriente" (ANTOINE, 1738-1742, p. 1964). No Dicionário Inglês Etimológico Universal, indicava-se que o serralho era o espaço em que o Grão-Senhor mantinha as suas concubinas (BAILEY, 1731, [s. p.]). E, por fim, no multilíngue Dicionário imperial, que apresentava definições nos idiomas italiano, francês, alemão e latim, e que foi publicado em 1766, exibia-se a informação "lugar, em Constantinopla, em que ficam fechadas as concubinas do imperador turco" (PLACARDI, 1766, p. 502).

Como ressaltavam os autores dos dois citados dicionários alemães e do dicionário multilíngue, o serralho, como um espaço físico, possuía uma característica peculiar: era um lugar inacessível. Johann Theodor Jablonski, em 1721, e Johann Heinrich Zedler, a partir de 1732 - no dicionário que contava com 64 volumes e outros quatro livros suplementares -, salientavam quase nos mesmos termos que o serralho era um local em que os islâmicos se fechavam com as suas mulheres e com os seus filhos. Nos dois dicionários alemães, havia a entrada para o termo "harém". 
O Dicionário imperial, por sua vez, indicava que se tratava de um "lugar fechado" (PLACARDI, 766, p. 502).

Um elemento de grande interesse para o assunto tratado aqui se refere às fontes usadas pelos autores de alguns desses dicionários. As referências encontradas em dois dicionários alemães e em um francês são de escritores de viagem. Na definição de harém, Zedler citou tanto o veneziano Pietro Della Valle (1586-1652) - conhecido como um dos mais importantes viajantes ao Império Safávida - quanto Jean-Baptiste Tavernier (1605-1689), indicando, nesse último caso, "Relac. de Serrail", o que certamente fazia menção à sua obra sobre o serralho do governante otomano, publicada pela primeira vez em Paris entre 1664 e 1665.

Entre os nomes de Della Valle e de Tavernier, figurava a abreviatura "Olear.". Uma vez que as observações feitas nesse espaço citavam nomes de viajantes, é certo que a abreviação indicasse Adam Olearius (1599-1671), secretário alemão de Frederick III (1597-1659), governante do ducado de Schleswig-Holstein-Gottorp. Em virtude dessa função, Olearius empreendeu uma viagem à Pérsia com o objetivo de negociar uma nova rota de comércio da seda. A embaixada partiu em missão em 1635, chegando à Corte Safávida em 1637. A primeira edição da narrativa de sua viagem sairia em 1647 . Uma segunda edição, ampliada, veio a público em 1656, sendo então traduzida para o holandês, francês, italiano e inglês (SOHRABI, 2005, p. 635). Jablonski, na entrada "Harém", também inseriu os nomes de Della Valle e de Olearius, nesse caso, com a mesma abreviatura usada por Zedler: "Olear.". Cabe lembrar que, nos dois dicionários alemães, o harém era definido somente como o aposento das mulheres islâmicas. 
O Dicionário de Trévoux, por sua vez, fazia menção a Clousier Du Loir, que havia viajado em 1639 para o Império Otomano, onde permanecera por dezessete meses (ANTOINE, 1738-1742). Embora não seja possível apontar com maior precisão os seus dados biográficos, sabe-se que Du Loir estudou a língua turca (POUILLON, 2008, p. 326). As dez cartas escritas no Levante e endereçadas a autoridades do governo francês foram publicadas em 1654. Uma curiosidade a respeito dessa obra é que o seu revisor e corretor era François Charpentier, o mesmo que teria trabalhado no texto de Jean Chardin (POUILLON, 2008, p. 325). Os trechos selecionados pelo Dicionário eram aqueles que descreviam as características externas do serralho, entendido por Du Loir como o palácio do Grão-Senhor otomano. O viajante afirmava que a aparência externa dessa construção não era "bela", porque a arquitetura não "era muito regular" (ANTOINE, 17381742, p. 1964; DU LOIR, 1654, p. 42-43).

O mesmo tipo de fonte de pesquisa também era aludido naquela que é considerada a enciclopédia mais importante do século XVIII - ainda que tenha a metade dos volumes da enciclopédia editada por Johann Heinrich Zedler. A Enciclopédia francesa [L’Encyclopédie ou Dictionnaire raisonné des sciences, des arts et des métiers], editada de 1751 a 1772 , apresentava no seu tomo quinze o termo "serralho" como "uma casa grande e ampla, um palácio" (DIDEROT; D'ALEMBERT, 1765, tomo 15, p. 77). Além de serralho denotar o palácio do Grão-Senhor, a palavra era usada como sinônima de "hospedarias públicas", chamadas de "caravançarás". Foi justamente na discussão sobre a grafia deste termo que o nome do 
viajante Jean de Thévenot foi citado. Afirmava-se que, durante a sua viagem à Índia, o viajante havia optado pela forma "quervan-serai", e não pelo uso "vicioso" da palavra serrail.

No mesmo volume da "Enciclopédia", havia a entrada para a palavra "Serrail", ao lado da indicação "Arquitetura turca". Nesse item, desenvolvido em três páginas, a descrição feita era sobre o palácio otomano em Istambul. O serralho era definido como um "palácio destinado a fechar as sultanas e os escravos do imperador turco e persa” (DIDEROT; D’ALEMBERT, 1765, tomo 15, p. 114). Mais adiante, o serralho seria comparado a um tipo de prisão (p. 927). As mulheres trancadas no serralho não tinham outra função senão divertir o sultão e irritar os eunucos. Mais uma vez, e como notado anteriormente em relação aos dicionários alemães e ao "Dicionário de Trévoux", a literatura de viagem também teve a sua influência nesta obra. $\mathrm{O}$ autor citado neste trecho era o viajante francês Joseph Pitton de Tournefort, de quem me ocuparei ainda neste capítulo. Na conclusão desse item, afirmava-se que as sultanas eram as escravas menos infelizes do mundo, mas o autor ironizava, alegando que a liberdade era preferível a uma felicidade tão frágil (DIDEROT; D'ALEMBERT, 1765, tomo 15, p. 928). A definição do termo harém ocupava apenas cinco linhas e era similar ao que se anunciava em relação ao serralho: tratava-se da casa na Pérsia onde eram "fechadas as mulheres e as concubinas" à semelhança do serralho na Turquia (DIDEROT; D'ALEMBERT, 1765, tomo 8, p. 41). Dadas as indicações dicionarizadas dos termos harém e serralho, passemos à verificação do uso desses termos na literatura de viagem do mesmo período. 


\subsection{Harém e serralho nas narratívas de víagem}

\subsubsection{Narratívas escrítas em ínglês}

Após a sistematização de oito viagens Seiscentistas por terras islâmicas esboçada no capítulo anterior, encontraremos no século XVIII uma narrativa de viagem feminina. A obra é fruto da viagem de Mary Wortley Montagu (1689-1762) que em 1716 acompanhou o seu marido, Edward Wortley Montagu, em sua função de embaixador em Istambul. A permanência do casal em terras otomanas até 1718 permitiu que Lady Montagu produzisse uma série de cartas que somente seria publicada em 1763, em três volumes. Menos de vinte mulheres inglesas publicaram as suas narrativas de viagem ao longo do século XVIII, e Montagu foi certamente a pioneira deste gênero (CLARK, 1999, p. 113). A publicação de seu livro, porém, teria ocorrido contra a vontade de sua família (BOHLS, 1995, p. 24). Entre agosto de 1716 e novembro de 1718, Lady Montagu escreveu 58 cartas para destinatários não identificados, em 24 cidades da Europa, da Ásia e da África.

Dois elementos chamavam a atenção do leitor logo na capa do livro. O primeiro deles dizia respeito ao nome da autora. Era possível verificar que se tratava de uma mulher, uma vez que a palavra "Lady" era indicada abaixo do título da obra: Letters of the Right Honourable Lady. Entretanto, não se conseguiria identificar o nome de tal senhora. O que se seguia após o "Lady" era a sequência "M_y W_y M_e". Como se poderá inferir, essas iniciais indicavam Mary Wortley Montagu, sendo o seu último sobrenome grafado, nesse caso, como Montague. 
O segundo elemento dizia respeito à afirmação colocada abaixo do título. Além de conter "relatos curiosos" sobre a "política e os costumes dos turcos", explicava-se que tais informações haviam sido elaboradas a partir de fontes "inacessíveis" a outros viajantes. Um traço notório da literatura de viagem era a busca por destacar a particularidade de determinada narrativa perante todas as outras. Tal prática foi seguida de perto por Lady Montagu, que não apenas insistiu em proceder desse modo, como faria oposição aos outros viajantes homens. Este fato, contudo, não impediu que o seu livro fosse dirigido a "pessoas de distinção" e a "homens de letras", em "diferentes partes da Europa".

Aos que tivessem acesso ao livro, não restaria dúvida de que a obra da "senhora" em questão diferia dos textos dos outros viajantes homens. Em primeiro lugar, a "ilustre autora" tivera oportunidades que nenhum outro viajante usufruíra antes. Além disso, o seu texto apresentava uma "elegância natural", uma "delicadeza de sentimento e observação", a "graciosidade fácil" e uma "adorável simplicidade" que eram a "perfeição da escrita" (MONTAGUE, 1763, vol. 1, p. vi). Mas a grande diferença entre ela e os outros viajantes estava no fato de ser a autora uma mulher. Para ela, as viagens feitas pelas mulheres tinham uma proposta muito melhor do que aquelas empreendidas pelos homens. Elas possuíam "a habilidade de explorar um novo caminho e embelezar um assunto desgastado com uma variedade de entretenimento arejado e elegante" (p. viii). Por todas essas razões, o leitor poderia se assegurar de encontrar em seu texto o "registro mais verdadeiro e preciso" sobre os costumes de vários povos com quem Lady Montagu havia conversado. 
A autora inglesa insistiu ao longo de toda a sua narrativa neste elemento: o seu texto era integralmente verdadeiro, afinal, ela registrara ali apenas o que havia presenciado. A insistência de Lady Montagu neste tema servia ao mesmo tempo para mostrar a autenticidade de seu próprio texto e para depreciar as várias narrativas de viajantes-homens com presença no Levante. Isso se justificava, em suas Cartas, pela dificuldade que os viajantes tinham em obter informações junto aos turcos, além da curta estadia dos viajantes - o que os impedia de comunicar qualquer coisa com exatidão de seu conhecimento. No seu relato, ao contrário, não se encontrava o puro divertimento, artifício este muito usado por outros viajantes para entreter os seus leitores (MONTAGUE, 1763, vol. 1, p. 111).

Ainda que houvesse tanta ênfase nas diferenças possíveis entre as narrativas de uma viagem feita por um homem e por uma mulher, um apelo era registrado ao final do Prefácio. O pedido era para que o leitor recebesse o texto de Mary Montagu, abandonando qualquer "inveja diabólica" e, caso reconhecesse os triunfos femininos, que os coroasse com louros a seus pés. Abaixo do Prefácio, e sem assinatura, constava um trecho em que se lia: "Você vê, Senhora, como eu dispus tudo a seus pés. À medida que a tautologia mostra a pobreza do meu gênio, ela também mostra a extensão do seu império sobre a minha imaginação" (MONTAGUE, 1763, vol. 1, p. xii).

As cartas de Lady Montagu, de fato, não pretendiam acentuar as diferenças entre os leitores e as leitoras. Isso pode ser percebido na Nota do Editor. Ali, o responsável pela edição das Cartas afirmava que a obra era digna de "todos os homens de bom gosto" e também de "todas as 
mulheres de classe". No caso das leitoras femininas, o editor lembrava ainda que, caso elas vissem a beleza como algo insípido, quando não temperada pelos "encantos intelectuais", poderiam encontrar nas Cartas o que estavam procurando e poderiam contemplar um "ornamento e um modelo para o seu sexo” (MONTAGUE, 1763, vol. 1, p. xv).

Além de ser uma narrativa feminina, o texto de Lady Montagu possuía outra diferença em relação às narrativas anteriores: a sua viagem - ainda que tivesse como destino principal a cidade de Istambul - não se restringiu a descrever este lugar. Ao invés disso, é possível ler os detalhes de sua viagem por várias cidades, inclusive na Europa. Desse modo, a narrativa permite que se faça uma análise comparativa entre as suas observações sobre a Europa - com as particularidades dos locais ali citados - e o Império Otomano, exemplificado na sua capital, Istambul.

Embora as cartas relativas ao Império Otomano apenas começassem a ser escritas em fevereiro de 1717 [Carta XXIV], o "tema dos turcos" criava uma tensão já desde o momento em que Lady Montagu se punha a descrever os costumes e a cidade de Viena; afinal, fora ali que se dera o episódio conhecido como o "Cerco de Viena" pelos turcos, ocorrido em 1529, além da "Batalha de Viena", no ano de 1683. Na Carta XX, de janeiro de 1717, Lady Montagu lembrava que o carnaval estava chegando e que neste momento toda sorte de divertimentos era liberada, à exceção da máscara, "que nunca é permitida durante uma guerra com os turcos" (MONTAGUE, 1763, vol. 1, p. 108). Este elemento se somava ao fato de a narrativa salientar a palavra "Turcos" na capa, em detrimento dos vários outros povos citados na obra. Não é demais 
lembrar que as Cartas passaram a ser comumente conhecidas como Turkish Embassy Letters, ou Cartas da Embaixada da Turquia.

O seu primeiro contato com um turco ocorreu na cidade de Belgrado que estava, a essa época, dominada pelos otomanos. Para que a comitiva do Sr. Montagu pudesse entrar em domínios otomanos, uma carta fora enviada ao baxá da cidade e, após certa tensão promovida pelo encontro entre tropas otomanas e germânicas, os visitantes tiveram a entrada liberada. Em suas frequentes conversas com o seu anfitrião, Achmet Beg, por meio de intérpretes ${ }^{35}$, Lady Montagu fez alusão ao primeiro tema relativo às mulheres islâmicas: o confinamento feminino. $\mathrm{O}$ anfitrião responderia que não havia nada demais nisso e que podia mesmo se tratar de uma vantagem, porque, caso suas esposas os enganassem, ninguém saberia disso (MONTAGUE, 1763, vol. 1, p. 149).

Nas Cartas de Lady Montagu, a apresentação do serralho não diferia completamente daquela já lida em viajantes anteriores. Então, a autora utilizou tal termo para significar o espaço físico. Mas a ênfase era dada ao caráter privado que envolvia o serralho - ou, como ela também nomeava, "Haram" -, afirmando que se tratava dos apartamentos das mulheres. Aliado a isso, a autora também ressaltou o privilégio desfrutado por este lugar, uma vez que, mesmo no caso de um baxá ser executado, os direitos deste espaço nunca seriam violados (MONTAGUE, 1763,

35 Mary Montagu utilizou intérpretes ao longo de sua permanência em terras otomanas, mas se interessou em estudar a língua e a cultura turca durante este período, indicando em março de 1718 que já entendia esta língua. Ver Letter XXXIX (MONTAGUE, 1763, vol. 1, p. 163-164). 
vol. 1, p. 147). Essas afirmações, de fato, não contrariavam o que já havia sido escrito pelos viajantes anteriores. Contudo, uma posição inédita a respeito das mulheres turcas era adicionada por Montagu: para ela, eram as mulheres "as únicas pessoas livres do Império" (MONTAGUE, 1763, vol. 2, p. 35).

Para sustentar tal posição, a autora buscou pontuar de que modo se dava a demonstração de poder feminino. Montagu lembrou que eram as mulheres as "rainhas de seus escravos", e não os seus maridos, como pudemos ler nas narrativas de viagem citadas até aqui - informação que, por suposto, reorganizaria as instâncias de poder dentro do espaço privado. Somem-se a isso as suas observações sobre a poliginia. Embora a autora afirmasse a possibilidade de um homem esposar até quatro mulheres, a sua conclusão era contundente: não havia "homens de qualidade" que fizessem uso dessa "liberdade", nem mulheres de "posição" que sofressem em razão dela (MONTAGUE, 1763, vol. 2, p. 36). Ela afirmava ainda que havia homens que mantinham amantes, mas que estas viviam em casas distantes e recebiam visitas reservadas, o que a levava a concluir que "os costumes da humanidade não diferem tão amplamente como os nossos escritores de viagem nos fariam acreditar" (MONTAGUE, 1763, vol. 2, p. 37).

$\mathrm{Na}$ Carta LV, de setembro de 1717, a autora voltava a insistir que as mulheres turcas não eram, de fato, "tão confinadas como muitos têm relatado". Ali, Lady Montagu tanto ressaltava os métodos de disfarce que muitas mulheres usavam em seus encontros amorosos quanto destacava o alto grau de liberdade feminina mesmo no "seio da 
escravidão". A contrapartida à liberdade desfrutada pelas mulheres turcas foi apresentada nos dois momentos em que Lady Montagu apresentou esta ideia, isto é, a de que as punições sofridas por elas eram muito severas. Uma vez descobertos os seus casos amorosos, os maridos saciavam o seu ódio através do sangue (MONTAGUE, 1763, vol. 3, p. 30). A respeito das punições sofridas pelas mulheres, a autora mencionava o caso de uma jovem moça, "tão surpreendentemente bela", que havia sido encontrada nua com duas marcas de facadas, na cidade de Pera [ou Gálata]. Com pouca investigação, o corpo havia sido enterrado, sem maiores rumores (MONTAGUE, 1763, vol. 3, p. 33).

No volume II da obra, Montagu voltaria a tratar o tema do serralho, apontando ser este um assunto pouco conhecido entre os europeus. Ao se encontrar com a sultana Hafiten - favorita e viúva do sultão Mustafa II (16641703) -, a autora quis aprender tudo o que era possível sobre o serralho, "que é tão inteiramente desconhecido entre nós” (MONTAGUE, 1763, vol. 2, p. 155). Antes disso, Lady Montagu havia visitado o harém na casa de Fatima, filha do sultão Ahmed III (1703-1730), espaço este que contava com a proteção de eunucos negros e com a presença de "belas garotas". Na visita a Hafiten, o tema das relações entre ela e Mustafa II ganharia destaque. Isso não era feito, contudo, sem uma menção às informações, na sua visão, equívocas propaladas a respeito do serralho. Para Montagu, a sultana havia afirmado que a "história do sultão jogando um lenço é totalmente fantasiosa" (p. 155). Cabe recordar que uma "história" como essa já havia aparecido em Michel Baudier, autor analisado no capítulo anterior, no momento em que ele descrevia de 
que modo ocorria a escolha da jovem que passaria a noite com o sultão. Depois de caminhar muitas vezes entre as jovens mulheres, e de ter o espírito envolvido pelos olhos daquela que mais o agradava, o autor afirmava que "ele [o sultão] joga o seu lenço para mostrar que está vencido [...]" (1631, p. 48). Louis Deshayes de Courmenin também incluíra tal episódio na segunda edição da sua narrativa (1629, p. 158-159).

As Cartas de Lady Montagu construíram-se de modo diverso do que presenciamos em outros viajantes até o momento. Ou seja, não se encontrará em sua obra um sistema rígido de descrição do harém, com uma ordem marcada e com assuntos comuns a outras narrativas de viagem. Mas ainda que fosse desse modo, o tema do prazer relacionado ao harém também apareceu em Montagu. Esta posição era revelada na Carta LV de setembro de 1717, mas nela não havia indicação da cidade em que estava a autora no momento de sua redação.

Após reprovar a forma de conduta do governo otomano, e a sua "voluptuosidade indolente", Lady Montagu chamaria a atenção de seu interlocutor para o fato de não ser ela inimiga do prazer, desde que este fosse "devidamente temperado" e "bem combinado". Abria-se, então, espaço para a sua afirmação seguinte: "A paixão deliciosa do serralho é a única que está quase inteiramente satisfeita aqui” (MONTAGUE, 1763, vol. 3, p. 29). Essa forma de prazer era, contudo, combinada com o despotismo, por um lado, e com o abatimento e a ansiedade, por outro. Logo, tratava-se de um "tipo misto" de prazer. A julgar pelo que vinha em seguida, é provável que Montagu estivesse pensando o prazer do harém como equivalente a 
demonstrações de grandiosidade e de riqueza. O prazer não se referia, portanto, a um domínio erótico, mas se relacionava a outro tema também abordado pelos viajantes anteriores: a suntuosidade dos palácios islâmicos.

Lady Montagu não se estendeu sobre o tema das paixões no serralho e pouco destaque concedeu à riqueza otomana. Esta posição deve ser lida certamente à luz do discurso verídico adotado pela autora ao longo de suas cartas. Ou seja, Mary Montagu insistia, de forma recorrente, na necessidade que seus interlocutores tinham em saber assuntos inéditos ou curiosos sobre o Levante. Mas, em igual medida, sempre afirmava a idoneidade de suas observações. Como não temos acesso às cartas enviadas para a autora por aqueles que eram seus interlocutores, não será possível afirmar que a demanda por novidades fosse um pedido feito a ela. De todo modo, a insistência de Montagu na obrigação de relatar episódios "extraordinários" - sempre colocada na pena de seus destinatários e não na sua própria - era uma forma de realçar o valor de verdade da sua narrativa em contraposição às posturas duvidosas de outros viajantes. Exemplo disso é o que se lê na Carta XXI, na qual a autora reclamava que determinada senhora não havia apreciado as suas cartas e que estava "muito brava" porque ela não iria "mentir como os outros viajantes” (MONTAGUE, 1763, vol. 1, p. 119). Conclui-se disso que Montagu preferia não se alongar sobre assuntos dos quais possuísse poucas informações.

Essa atitude foi retomada em vários outros momentos de suas cartas, fosse para criticar a "imaginação ridícula" da senhora anônima da Carta XXI; fosse para apontar o previsível desapontamento das pessoas que a receberiam 
em Londres, esperando por "raridades" em sua jornada; fosse, ainda, para reprovar as informações de outros viajantes, como na passagem em que ela afirmava que os viajantes-escritores comuns gostavam muito de falar sobre assuntos que eles não conheciam (MONTAGUE, 1763, vol. 2, p. 73). Este último item era particularmente explorado em Montagu. Na Carta XXXVII de 17 de junho de 1717 , a autora criticava nominalmente um viajante - Jean Dumont - por escrever com "ignorância” sobre a Turquia, afirmando que os viajantes faziam relatos sobre "as mulheres que, é certo, eles nunca viram, e falam com muita sabedoria sobre o gênio dos homens, em cuja companhia nunca são admitidos, e muitas vezes descrevem mesquitas que nem mesmo se atrevem a espiar" (MONTAGUE, 1763, vol. 2, p. 131). Diante desses relatos tão cheios de “absurdos”, Lady Montagu assumia se divertir muito.

A autora, porém, não se furtou a relatar um episódio inédito à literatura de viagem masculina a fim de entreter a sua interlocutora. Como ela mesma dizia, estava indo para um "mundo novo", e foi em Adrianópolis [atual Edirne] que essa novidade revelou-se a seus olhos. A viajante inglesa pôde acompanhar o funcionamento de um banho público [hammām], no qual cerca de duzentas mulheres comportavam-se de forma muito "polida", sem exibir "sorrisos desdenhosos e sussurros satíricos" (MONTAGUE, 1763, vol. 1, p. 160-161). A autora assumiu uma posição de observadora, uma vez que não participou do banho. Nem mesmo chegou a se despir, em razão de um espartilho, fato que levou as mulheres turcas a afirmarem que tal vestimenta se resumia em uma "máquina" da qual ela não podia se livrar. Tratava-se mesmo de um artifício de seu marido. 
Para além da detalhada descrição de Montagu a respeito da beleza, da idade e das atividades das mulheres que ali estavam, um elemento merece a nossa atenção: o instrumento pelo qual a autora interpretou esse cenário. É certo que a nudez e as características físicas destas mulheres foram registradas por ela, mas tais informações foram suplantadas pelo valor estético que tal lugar anunciava para a autora. Observava Montagu que algumas mulheres pareciam ter sido "desenhadas pelo lápis de Guido ou Ticiano". Como ela completava, "para dizer a verdade, eu tinha malícia suficiente para desejar secretamente que o Sr. Gervais ${ }^{36}$ pudesse ter estado lá de forma invisível" (MONTAGUE, 1763, vol. 1, p. 162).

$\mathrm{Na}$ sua percepção, essas mulheres não possuíam "gestos indecentes", e o hammām mais se assemelhava a uma "casa de café das mulheres, onde todas as notícias da cidade são contadas, escândalos [são] inventados etc." (MONTAGUE, 1763, vol. 1, p. 163). Por tais razões, a narrativa de Mary Montagu é lida por Elizabeth Bohls como sendo responsável por duas grandes contribuições. O seu texto pressupõe a existência de uma nova estética - aquela que busca (des) erotizar e dignificar "as mulheres turcas, a quem os viajantes anteriores haviam incansavelmente objetificado" (1995, p. 12). Isso abriu espaço, por conseguinte, para que Montagu confrontasse o discurso tradicional vigente e neutralizasse o "Orientalismo nascente" (p. 17).

Se o livro de Lady Montagu demorou mais de quarenta anos para ser publicado, o registro de viagem do

36 O Sr. Gervais em questão era o pintor irlandês Charles Jervas (c. 16751739). 
clérigo protestante Richard Pococke (1704-1765) teria o seu primeiro volume lançado apenas um ano após a sua viagem e seria considerado, dentre os livros de viagem ao Levante, o "mais completo e o de maior autoridade" no século XVIII (HACHICHO, 1964, p. 36). As suas viagens por regiões islâmicas, que incluíram o Egito e a Palestina, iniciaram-se em fins de 1737 e se estenderam até 1742. O primeiro volume de A description of the East, and some other countries foi publicado em 1743, e o segundo, em 1745.

O gosto de Pococke por temas relacionados ao Levante e às ciências fez com que ele se tornasse membro do "Egyptian Club", da "Spalding Society" e também da "Royal Society", em fevereiro de 1741 (HACHICHO, 1964, p. 37). O "Egyptian Club" nasceu do empenho do próprio Pococke ao lado de outro viajante, o dinamarquês Frederick Lewis Norden, em estabelecer um grupo de estudos sobre a história antiga do Egito. Já a "Spalding Society" foi organizada na primeira década do século XVIII com o objetivo de discutir a história antiga da Grã-Bretanha, além de se analisarem as notícias do jornal "The Tatler". Ao lado disso, Pococke também se dedicou a estudar "as principais línguas orientais" (JOHN, 1837, vol. 2, p. 101).

Em 20 de maio de 1736, Pococke saiu de Londres em direção ao Leste. Viajando pela Holanda, pela Alemanha e pela Itália, ele embarcou no porto de Livorno, em 7 de setembro de 1737, com destino a Alexandria, onde chegou no dia 29 do mesmo mês. No seu livro, o clérigo deixaria registrado que as "magníficas construções do Egito" e a sua arquitetura antiga seriam os principais temas ali 
registrados, o que não o impediria, contudo, de se dedicar a assinalar "os modos e os costumes de um povo tão diferente do nosso" (POCOCKE, 1743, vol. 1, p. iii). Curiosamente, o autor admitia que o seu texto poderia conter erros, mas esperava que os leitores entendessem que a sua narrativa havia sido feita a partir das coisas como elas são.

Já no Capítulo I do Livro I, Pococke mencionava que, ao chegar ao porto de Badjoura [no Alto Nilo], ele encontrara o Bei acampado no harém com as suas senhoras $(1743$, vol. 1, p. 124). O termo também era grafado no capítulo dedicado aos costumes do povo egípcio. A palavra usada foi novamente "harém" e não "serralho", como apareceu na maioria dos viajantes lidos até aqui. No momento em que escrevia sobre os hábitos alimentares dos turcos que viviam no Egito, o autor ressaltava: "quando eles não têm companhia normalmente vão para o harém, ou apartamentos das mulheres, na hora de comer" (POCOCKE, 1743, vol. 1, p. 183-184). Caso se tratasse de um "grande homem" casado com quatro esposas, então, haveria cinco cozinhas: uma para cada mulher e uma para "entretenimentos públicos". Esta última servia para a ocasião em que tal homem resolvesse jantar fora do harém.

O emprego do termo harém para se referir a um espaço físico privado - fosse em tendas ou em palácios não é a única definição que aparece no relato de Pococke. $\mathrm{Na}$ província de Arsinoe $^{37}$, o clérigo encontrou ruínas que pareciam ser de pirâmides. Então, ele ressaltou que essas construções eram chamadas de "pirâmides de

37 Nome de uma antiga cidade situada no norte do Golfo de Suez, no Mar Vermelho. 
Baiamout", ou "Al-Harem-Baiamout" (POCOCKE, 1743, vol. 1, p. 57). Como se pode verificar, a expressão "as pirâmides”, em árabe, grafa-se Al-Ahram (الأهرام), cuja pronúncia é muito parecida com a da palavra harém. Este fato, por suposto, levou o autor a cometer tal equívoco.

Embora o clérigo tenha sido bastante cuidadoso com as suas descrições a respeito das construções físicas vistas no Egito, pode-se notar uma imprecisão no emprego dos termos serralho e harém. No capítulo dedicado a descrever o Bei de Túnis, assim como a sua Corte e o seu governo, Pococke usou as duas palavras para se referir ao espaço privado feminino dentro do palácio, mas não se empenhou em demonstrar possíveis diferenças entre elas. Em um momento, o autor afirmou que à noite o Bei caminhava em direção ao "serralho das mulheres". Em outro momento, o Bei dormiria em sua própria cama e poderia acordar à noite e ir para o "harem" (POCOCKE, 1743, vol. 1, p. 267). Nesse caso, serralho e harém poderiam ser entendidos como lugares distintos pelos leitores.

A palavra serralho usada como sinônimo de palácio já havia sido citada quando o autor descreveu a arrecadação de renda nas cidades egípcias destinada ao Grão-Senhor otomano. Uma parte desse dinheiro era utilizada para consertar os castelos e para a compra de "grandes estoques de açúcar e shirbets [bebidas] para uso do Serralho" (POCOCKE, 1743, vol. 1, p. 172). Emprego similar pode-se notar no capítulo referente às "tropas militares" no Egito. Ali o autor afirmava que as guarnições de circassianos guardavam o "serralho dos sultões" (p. 166). De forma proposital ou não, serralho foi escrito com inicial maiúscula e, depois, com letra minúscula. 
Ao final do primeiro volume, em seu "índice" - que pode ser entendido como um índice remissivo -, Pococke listou a palavra harém, relacionando-a ao espaço de convívio feminino: "Haréns ou apartamentos das mulheres". Ao lado disso, indicava-se "Ver Mulheres" (POCOCKE, 1743, vol. 1, p. 302). Nesse índice, entretanto, não foi assinalada a palavra serralho conforme o seu uso no texto. Não havia qualquer menção também à possibilidade de as mulheres viverem fechadas dentro de seus apartamentos. A única referência à reclusão feminina era feita no momento em que o autor descrevia os banhos públicos. $\mathrm{Na}$ sua visão, as mulheres ficavam contentes quando podiam sair do "confinamento" e ir aos banhos (p. 37).

No volume $2 \mathrm{da}$ obra $^{38}$, Pococke registrou apenas uma vez a palavra harém. Na parte I desse volume, o clérigo usou este termo para nomear a área de convívio feminino dentro da tenda. Ele informava que os árabes mantinham tal espaço, mas que não eram tão "escrupulosos como os turcos com relação às suas mulheres", pois, assim que os árabes estivessem familiarizados com os novos convidados, permitiam que entrassem em suas tendas (POCOCKE, 1745, vol. 2, parte 1, p. 5). Em uma publicação sobre alguns livros de viagem no século XIX (JOHN, 1837, vol. 2, p. 112), esta passagem foi escrita de modo a acentuar a convivência entre Pococke e as mulheres árabes. No livro em questão, afirmava-se que o anfitrião árabe havia saído da tenda e deixado o clérigo sob

38 A Parte I do Volume II se refere à viagem pela Palestina, “Terra Santa”, Síria, Mesopotâmia, pelo Chipre e por Candia. A Parte II compreende a viagem pela Ásia Menor, Trácia, Grécia e por “algumas outras partes da Europa”. 
os cuidados das mulheres árabes. Mas pelo texto original é possível saber que Pococke ficou sentado na tenda com as mulheres dos árabes e com outras pessoas (POCOCKE, 1745, vol. 2, parte 1, p. 5).

O termo serralho, por sua vez, era usado no momento em que ele se referia ao palácio real na Síria. Este serralho tinha, na sua visão, "um ar de palácio romano" (POCOCKE, 1745, vol. 2, parte 1, p. 91). Na Parte II, as referências são mais abundantes. Pococke empregou o termo serralho logo no início do livro, também com letra inicial minúscula, para aludir ao palácio do Grão-Senhor (POCOCKE, 1745, vol. 2, parte 2, p. 4). A palavra serralho apareceu ainda em mais oito páginas da obra, sempre tendo como referência o palácio imperial otomano. O autor lembrava aos seus leitores da grande atenção recebida pelo tema do serralho até então, e completava afirmando que "não é permitido que ninguém entre no serralho sem uma ordem particular de Constantinopla" (POCOCKE, 1745, vol. 2, parte 2, p. 141).

Ainda que não se encontre uma ligação necessária entre a lassidão de costumes e o harém, o tema da sensualização feminina também foi mencionado por Pococke. Foi em sua passagem pelo Chipre, território dominado pelos otomanos, que o autor escreveu: "as mulheres são pouco superiores aos seus ancestrais em relação à virtude; e como elas andam sem véu, expõem-se de uma maneira que, nessa região, é vista como muito indecente" (POCOCKE, 1745, vol. 2, parte 1, p. 232). Isso não impediu, contudo, que o autor reprovasse um "bárbaro costume" visto nestas terras: o fato de os homens tratarem as suas esposas como servas. Essa relação de submissão 
feminina apenas não ocorria nas famílias que possuíam contato mais estreito com os europeus e que se tornavam, portanto, "civilizadas".

$\mathrm{Na}$ ilha de Candia, o tema do véu era novamente abordado, mas dessa vez para sinalizar o seu uso pelas mulheres turcas. É certo que, cobertas pelo véu, as mulheres não poderiam exibir a sua beleza. Então, Pococke apresentava um argumento apoiado no senso comum. $\mathrm{Ou}$ seja, ao invés de se colocar como testemunha, ele afirmaria: "é dito que as mulheres turcas, que usam o véu, são mais bonitas do que as cristãs" (POCOCKE, 1745, vol. 2, parte 1, p. 266). A beleza das mulheres não foi a única característica a ser assinalada pelo autor. Logo na sequência desse trecho, ele indicava que as mulheres possuíam uma tendência para a "invenção" e para espalhar falsidades, além de acreditarem em "coisas estranhas".

A beleza das mulheres de Damasco também mereceu a atenção do autor, afinal, dizia-se que tais mulheres eram "as mais belas no mundo" (POCOCKE, 1745, vol. 2, parte 1 , p. 125). Os homens eram bonitos quando jovens, mas em virtude do calor, dos seus "vícios", dos banhos e do costume de usar barba, eles perdiam tal graciosidade na maturidade. É essa mesma chave de leitura que se pode encontrar na descrição dos homens turcos. Para Pococke, eles eram responsáveis por "perverter" as mulheres cristãs que viviam na ilha de Candia [atual ilha de Creta]. É importante ressaltar que o tema do calor e dos banhos era assinalado com recorrência pelos europeus, como será analisado no Capítulo 4.

A sugestão sobre os excessos sexuais dos muçulmanos era indicada no trecho em que o autor descrevia os 
damascenos. Para o clérigo inglês, o povo de Damasco [na Síria] era muito viciado no prazer e amava passar o seu tempo de forma indolente (POCOCKE, 1745, vol. 2, parte 1, p. 125). A sexualização das mulheres, especialmente, chamava a atenção do autor na ilha de Ipsara [ou Psara], em Chios, na Grécia. Embora as mulheres usassem véu, Pococke dizia que elas exibiam os seus seios de "maneira muito indecente" (p. 13). Mas a explicação dada pelo autor relativizava tal característica, uma vez que ele afirmava que esse costume se devia mais à "ignorância do decoro do que à lascívia" (p. 13).

A ilha de Ipsara estava sob o domínio otomano desde o século XVI. E, para assegurar a permanência de seu governo, os turcos mantinham relações diplomáticas com a Igreja ortodoxa grega. Uma aliança entre o governo otomano e a Igreja ortodoxa era uma forma de legitimar tal governo aos olhos dos súditos ortodoxos (ÁGOSTON; MASTERS, 2009, p. 236-238). Isso nos indica que, mesmo dentro de um governo otomano, o cristianismo ortodoxo continuava predominante nessa ilha. Portanto, é razoável encontrar em um clérigo protestante - como era Pococke - uma explicação que buscava ponderar a respeito de um elemento sexualizante em uma sociedade cristã.

Além do possível desinteresse pelo tema, havia uma razão fundamental para que Pococke não descrevesse em detalhes o harém real: ele não tinha entrado em um. Portanto, o que se pode encontrar em sua narrativa é uma abordagem que mais cerca o tema do que o trata efetivamente. De todo modo, fosse usando o termo harém ou serralho, o fato é que o clérigo notava a existência de um lugar privado de convívio feminino e sabia que o seu 
acesso era controlado, como já se indicou antes. Nesse sentido, a importância de seu texto reside, sobretudo, na abordagem do harém como um espaço físico. O uso de elementos sensuais ou sexuais notados nas sociedades muçulmanas, ainda que faça parte da composição de seu texto, não se resumia no tema de maior destaque em sua narrativa.

Os propósitos de Richard Pococke eram, de fato, bem distintos daqueles expressos na última narrativa inglesa a ser analisada neste capítulo. Ao contrário do clérigo, a nossa última autora pretendia tratar as características sociais do Império Otomano, concedendo um espaço da sua narrativa à descrição do harém. Elizabeth Craven (17501828) fazia parte da elite social inglesa. Era a filha mais jovem do conde de Berkeley e, aos dezessete anos, casou-se com William Craven, que se tornaria o sexto barão Craven e com quem teve sete filhos. Em virtude de vários episódios de traição - de ambas as partes -, o casamento terminaria em 1783. Os termos da separação foram mais desfavoráveis a ela: Elizabeth Craven teve de se retirar para o continente, foi separada dos filhos - à exceção de um - e perdeu o apoio financeiro (TURHAN, 2003, p. 28).

Após a separação, Craven decidiu rumar em direção a Istambul e iniciou a sua viagem em 1785, em Paris. A viagem não se deu por convite, por convocação ou por um ímpeto aventureiro de Craven. Ela mesma assumiu que viajar era um "projeto amargo" para ela (CRAVEN, 1789, p. 195). Mais do que isso. Ela chegou a afirmar que odiava viajar, mas o fazia com um objetivo: "Eu estou determinada a ver o lugar onde a capital do mundo deveria ser colocada" (p. 195). Esse entusiasmo com a "capital do mundo" também foi tema dos viajantes Henry Blount e 
Louis Deshayes de Courmenin, no Capítulo 1, e gerava debate entre os autores do início da modernidade europeia (BOYAR; FLEET, 2010, p. 1).

Embora um novo casamento fosse oficializado apenas em 1791, foi a seu marido, Frederick Charles Alexander, Marquês de Brandenburg, Anspach e Bareith, que o livro seria dedicado e para quem as suas cartas foram escritas. A narrativa intitulada A Journey through the Crimea to Constantinople, publicada em 1789, demonstrava algumas aproximações com o texto de Lady Montagu. O objetivo de Craven era chegar ao mesmo lugar para o qual Montagu havia ido: Istambul. Além disso, a rota de Craven seguia também por países europeus. O seu relato adotou o mesmo formato usado por Montagu: a forma epistolar. E, por fim, Craven pretendia questionar as informações registradas por Lady Montagu (KOLOCOTRONI; MITSI, 2008, p. 8).

Diferentemente de Lady Montagu, a baronesa Craven decidiu publicar os seus escritos impulsionada pelos amigos que, sabendo de sua "longa e extraordinária jornada", desejaram que ela fizesse um registro sobre isso (1789, p. ii). Craven, então, informava aos leitores que a "maneira mais agradável" de relatar a sua viagem fora transcrever parte de suas cartas, dando a eles um "retrato fiel do que eu vi" (p. ii). Embora a publicação tenha saído três anos após o fim da viagem, as cartas de Craven possuíam lacunas no lugar dos nomes da maior parte das pessoas citadas na obra. Ademais, e ao contrário de Montagu, as suas cartas não pretendiam marcar uma fronteira entre a narrativa dos viajantes e das viajantes. No lugar disso, Craven preferiu se apresentar como uma senhora distinta, 
de bom gosto e independente, "honrada e estimada por todos aqueles com quem ela encontra, desde o humilde soldado à Czarina Catarina" (TURHAN, 2003, p. 32).

É na Carta VI, de 30 de junho de 1785, que Elizabeth Craven anunciou ao seu destinatário que não retornaria para Paris. Ao contrário. Ela afirmava que seguiria para o sul, pois havia recebido uma carta de seu "irmão" [o Sr. B.] - possivelmente, o Marquês de Brandenburg -, declarando que ele passaria o inverno na Itália. Craven, então, respondera ao Sr. B. que iria para Florença; lá, esperaria por ele. O marquês, contudo, não foi para o destino anunciado, o que levou Craven a seguir o seu caminho pelo norte.

Quando estava na Áustria, passando por Klagenfurt [cidade que dista $234 \mathrm{~km}$ de Viena], Elizabeth Craven fez a sua primeira crítica ao texto de Mary Montagu. É certo que ela não revelaria o nome da autora, mas, pela indicação, é possível aferir que se tratava de Montagu. $\mathrm{Na}$ Carta XXVIII, lê-se que "L.M._'s Letters" abusava da credulidade de seus leitores, uma vez que deturpava informações. O tema em questão eram os fogões que haviam sido elogiados por Montagu e tomados como "a invenção mais horrível” que se poderia conceber, na visão de Craven.

O tema - desimportante, aliás - não é o elemento mais sintomático da acidez de Craven contra Montagu. Nesse trecho, a baronesa desconfiava da veracidade das cartas de Mary Montagu, afirmando: "quem quer que [as] tenha escrito [pois ela nunca escreveu uma linha delas] deturpou as coisas da maneira mais terrível" (CRAVEN, 1789, p. 105). Logo em seguida, contudo, Craven assumiu a possibilidade de Mary Montagu ter escrito as cartas, 
ponderando que as "coisas devem ter sido muito alteradas desde que a senhora ou o cavalheiro escreveram sobre Viena" (p. 106). No seu livro de memórias ${ }^{39}$, publicado em 1826, Craven voltava a confirmar que as Cartas não haviam sido escritas por Lady Montagu e utilizou-se, para tanto, da declaração da própria filha de Montagu, Lady Bute. Segundo esta, Horace Walpole - aristocrata e romancista inglês - e mais duas pessoas haviam se unido para se divertirem "à custa da credulidade do público inglês, compondo estas Cartas" (CRAVEN, 1826, p. 117).

Das cartas escritas em Viena [iniciadas em dezembro de 1785] até à primeira menção ao harém, haviam se passado quatro meses. Foi na cidade de Bakhchysarai [na Crimeia, sul da Ucrânia] que Craven fez uma descrição da casa do "Khan" ${ }^{40}$, e inseriu o termo harém. Dentro deste palácio, havia uma variedade de apartamentos, sendo o harém "espaçoso e mais alto do que as outras construções” (1789, p. 179). Nesta mesma página, a palavra recebeu uma atenção particular em uma nota de rodapé: “o harém significa o apartamento onde as mulheres residem, e é sempre uma construção separada daquela em que o senhor habita; irmãs, mães, esposas, ou senhoras, todas habitam o harém" (p. 179).

Mais adiante, na Carta XLVI, a autora faria uso do termo serralho para se referir à moradia otomana, situada no Mar de Mármara. Craven afirmava ter visto o sultão sentado em seu sofá de prata. Logo em seguida, ela

\footnotetext{
${ }^{39}$ Memoirs of the Margravine of Anspach written by herself. Volume I e II. 40 Trata-se de um título político mongol e otomano, e pode ser traduzido por "soberano".
} 
mostrava o equívoco em torno do termo, explicando que "Serail, ou Seraglio" "é geralmente entendido por habitação, ou melhor, por confinamento para as mulheres". Mas a autora corrigiu essa percepção, completando que se tratava da "residência do sultão". Por fim, ela justificava que o serralho não poderia ser chamado de palácio, pois aquele possuía "quiosques ${ }^{41}$, jardins, pátios, paredes, estábulos, tão misturados", que implicava a presença de muitas casas em muitos jardins (CRAVEN, 1789, p. 204).

A sua posição sobre o confinamento feminino era somada às observações feitas sobre o espaço público. A autora afirmava que havia muitas mulheres nas ruas, mas que elas pareciam "múmias andando", uma vez que cobriam o corpo com um tecido que se estendia do pescoço ao chão. Ainda que fosse assim, Craven assumiu uma postura que já havia sido apontada por Mary Montagu. A baronesa defendia que não havia visto qualquer outro país “onde as mulheres podem desfrutar tão grande liberdade, [sendo] tão livres de reprovação, como na Turquia" (CRAVEN, 1789 , p. 205). Elas eram, de fato, as "criaturas mais felizes" que existiam (p. 234).

Embora Craven tenha buscado no trecho acima dissolver a imprecisão em torno da palavra serralho, o seu próprio texto não seguiu este pressuposto. Na Carta XLVIII, a autora usou a palavra serralho para se referir à residência do sultão, mas logo adiante empregou o termo harém com a mesma finalidade (1789, p. 221). Este, por sua vez, tanto podia indicar a residência do sultão quanto um espaço menor dentro de tal residência. $\mathrm{O}$ último caso

41 Quiosque era um pavilhão construído dentro do palácio otomano. 
pode ser encontrado no momento em que a baronesa visitou a casa de um baxá, comentando nunca ter visto um lugar tão arrumado e limpo, "como no interior de seu harém” (p. 224).

O harém, na versão de Craven, era também um tema de curiosidade para aqueles que não o tinham conhecido. Assim, ela alegava que "nossos cavalheiros estavam muito curiosos para ouvir um relato sobre o harém". Por tal razão, ela contou que no momento em que estavam saindo do harém, na cidade de Pera, o mensageiro correu até o seu grupo para pedir que a carruagem percorresse a Corte duas ou três vezes a fim de divertir a esposa do baxá e o harém. Ela terminava afirmando que essa "mensagem ridícula" não foi cumprida por eles - como o seu destinatário poderia imaginar. Eles voltaram para casa rindo de suas "aventuras" (CRAVEN, 1789, p. 226-227).

O caráter particular e feminino do harém foi notado por Craven na sequência de suas cartas. O harém foi tomado como um espaço sagrado, mesmo dentro de uma sociedade em que havia um poder político destrutivo. Era esse aspecto sagrado que protegia as mulheres turcas da "ociosidade, da curiosidade e da impertinência pública" (p. 233). Do mesmo modo, "seus talentos, sua beleza, sua felicidade, ou miséria" eram protegidos dos "observadores maliciosos" (p. 233). Mas isso não impedia a ocorrência dos percalços sentidos pelas mulheres dentro do harém. Como a autora notava, nas casas maiores as esposas dos turcos estavam destinadas a serem subservientes em relação à primeira esposa. Era esta que regrava a convivência do harém, de acordo com o seu prazer. 
Logo em seguida, a autora colocou em pauta um assunto muito presente nas narrativas de viagem: as paixões dos turcos. Como pudemos verificar até aqui, os viajantes ressaltavam as paixões dos muçulmanos - especialmente dos turcos - não tanto em relação às suas mulheres, mas em particular aquelas paixões devotadas aos jovens rapazes. Craven, entretanto, não seguiu estes passos. Além disso, a autora inseria uma informação - de acordo com o que tinha ouvido - que depunha contra as relações apaixonadas entre marido e esposa. Para ela, "o marido turco não enxerga a sua esposa como objeto de paixão, a não ser por um espaço muito curto de tempo" (CRAVEN, 1789, p. 233).

Elizabeth Craven não demonstrou uma curiosidade desinteressada pela sociedade otomana, como fizera antes dela Lady Mary Montagu, o que pode depor contra a posição de "discípula" da baronesa em relação a Montagu (MELMAN, 1989, p. 304). Se esta devotou grande atenção ao funcionamento do hammām, como mostrado anteriormente, Craven interpretou-o como um espaço de divertimento para "mulheres gordas", imersas na "arte e coquetismo" no arranjamento de suas vestimentas, o que a levou, por suposto, a recusar o convite de participar do banho. Ela justificava a sua rejeição a tal proposta afirmando que uma "visão tão repugnante como esta" lhe causaria um mau humor com as mulheres no banho por séculos (CRAVEN, 1789, p. 264).

Se a posição de Craven em relação às mulheres turcas era de certo desapreço ao longo de suas cartas, o mesmo não se pode dizer em relação ao harém. Embora as mulheres turcas fossem descritas como gordas e esteticamente pouco harmoniosas aos olhos da baronesa (1789, 
p. 264), isso não afetava a sua apreciação acerca deste lugar. Este espaço privado tinha o mérito de assegurar o direito feminino ao próprio corpo, uma vez que um homem não poderia entrar no harém caso visse um par de chinelos na porta (p. 205). Essa história seria repetida em seu livro de memórias para ressaltar o valor de liberdade desfrutado pelas mulheres turcas (CRAVEN, 1826, p. 166-167). Nas suas cartas, o harém não era reduzido a um espaço de dominação masculina, fato que levou Billie Melman a defender que a sua obra, assim como a de Lady Montagu, contribuíram para “(des) sexualizar” o Levante (1989, p. 301-339). Se Elizabeth Craven não se identificou com as mulheres muçulmanas - como fez muitas vezes Lady Montagu -, nem por isso encarou-as como mulheres subservientes aos homens. A sua visão oscilante em torno das turcas impeliu Craven a sugerir que aquelas que viviam no harém poderiam manter encontros secretos com homens disfarçados de roupas de mulheres, o que prova que, mesmo em uma narrativa feminina, as mulheres turcas não escapavam da alcunha de embusteiras (CRAVEN, 1826, p. 166-167).

\subsubsection{Narratívas escrítas em francês}

Seguindo o pressuposto de abarcar narrativas tão variadas quanto à formação de seus autores e à sua localização no tempo, o primeiro relato desta série será o de um autor que se dizia o primeiro francês a percorrer o "Oceano Oriental e o Estreito do Mar Vermelho". Jean de La Roque (1661-1745), homem de letras e um dos fundadores da "Académie de Marseille", publicou no ano de 
1716 a sua Voyage dans l'Arabie Heureuse, fait de 1708 à 1710, par l'Océan-Oriental et le Détroit de la Mer Rouge, avec la relation d'un Voyage fait du Port de Moka à la Cour d'Yémen, de 1711 à 1713.

O livro resultante desta viagem foi dedicado ao conde de Pontchartrain, então Ministro e Secretário de Estado do rei da França, e quem havia contribuído para a realização da viagem (1716, p. iv). Antes disso, em 1688, o autor já havia viajado para a Síria e para o Monte Líbano. Este texto seria publicado somente em 1722, momento em que o seu autor seria conhecido por sua viagem à península Arábica. Jean de La Roque era filho de um comerciante de Marselha, e foi nesta cidade que ele, ao lado de seu irmão, obteve licença para compor o jornal Mercure de France ${ }^{42}$. Ele e o irmão, Antoine de La Roque, trabalharam juntos nesse jornal até à morte deste, em outubro de 1744.

A viagem para a "Arábia Feliz", sinônimo para a região meridional da península Arábica, tinha o objetivo de instaurar o primeiro carregamento direto de café entre o Iêmen e a França sem o intermédio de comerciantes árabes, armênios ou turcos (MCCABE, 2008, p. 172). Além dos objetivos comerciais de sua viagem, Jean de La Roque possuía um intento científico que, nesse caso, era mapear a área por onde ele viajaria. Tratava-se de um longo percurso já que o autor saiu de Brest, no norte da França,

\footnotetext{
${ }^{42} \mathrm{O}$ Mercure de France tinha, ao lado da Gazette de France e do Journal des Sçavans, autorização do governo francês para funcionar, mas não era um "jornal governamental" no mesmo sentido que estes dois últimos. Sobre isso, ver Censer, 1994, p. 144 ss. O Mercure de France foi publicado entre 1672 e 1724 e encerrou as suas atividades em 1825 (DARNTON; ROCHE, 1989, p. 146).
} 
passou por Cádiz, na Espanha, percorreu o litoral oeste do continente africano, contornou o "Cabo da Boa Esperança” e continuou pela costa leste da África até alcançar o Golfo de Aden, no sul do Iêmen. O tema era certamente de interesse a muitos comerciantes e geógrafos europeus (BROTTON, 1997, p. 186). Por isso, não demoraria muito tempo para que o livro fosse traduzido para o italiano (1721) e para o inglês (1726).

A narrativa de Jean de La Roque possuía, por fim, uma marcada intenção teórica que era corrigir erros propalados sobre a península Arábica por outros autores, uma vez que os viajantes não tinham percorrido o interior da Arábia para "poder traçar uma descrição perfeita" (1716, p. xi). Para retificar tamanhas imperfeições sobre a geografia da península Arábica, o autor acrescentava ao texto um mapa do Reino do Iêmen, desenhado por Guillaume Delisle, da "Académie Royale des Sciences", com todo o "cuidado e exatidão" com que se era capaz (p. xii). As obras dos mais famosos geógrafos árabes haviam sido consultadas e o resultado era uma peça que primava pela novidade e pela justeza (p. xii-xiii). Some-se a isso o conhecimento que o autor possuía da língua árabe, pois ele deixou registrado que fizera a tradução de uma obra de Abul-Fidac (1273-1331), "geógrafo de uma grande reputação entre os árabes" (p. xiii). Ainda que fosse assim, o autor utilizou intérpretes árabes ao longo de sua viagem.

O primeiro livro de Jean de La Roque foi subdividido em cinco cartas - sem indicação de destinatários -, sendo a primeira menção aos apartamentos femininos feita na Carta II, quando o autor estava na cidade de Aden [localizada no sul do Iêmen]. No segundo dia de visita ao 
governador deste local, ele foi informado de que tal homem estava na "casa de suas mulheres" e pôde ver as janelas de onde "estas damas nos veem passar" (LA ROQUE, 1716 , p. 44). Se o autor não possuía informações de ordem empírica para relatar os aposentos femininos, ele pôde descrever as mulheres de Muḥā [cidade portuária do Iêmen, no Mar Vermelho] que caminhavam nas ruas.

$\mathrm{Na}$ realidade, não havia muitas mulheres andando nas ruas durante o dia. À noite, elas possuíam maior liberdade de locomoção e podiam visitar umas as outras. Sobre isso, Jean de La Roque afirmava que, caso encontrassem um homem em seu caminho, as mulheres o deixavam passar, ficando em silêncio e mantendo "grande modéstia" (1716, p. 92). Além do comportamento, a sua modéstia se referia seguramente às roupas usadas por elas. Vestimentas, aliás, que eram empregadas de modo geral por "todas as mulheres do Oriente" (p. 92). Este dado tinha como fonte as descrições dos viajantes, os quais chamavam a atenção do leitor para o fato de as mulheres usarem véus que cobriam os seus rostos.

$\mathrm{O}$ segundo momento de proximidade entre o viajante e as mulheres muçulmanas em recinto privado foi durante o seu alojamento em Muhā. Ele estava acomodado em uma casa que tinha como vizinho um jovem árabe. As casas eram separadas apenas por um corredor. As janelas da casa vizinha à sua possuíam uma construção ao modo de varanda, aonde as mulheres iam à noite "tomar a fresca" (LA ROQUE, 1716, p. 93). Essas mulheres ficavam sentadas em almofadas, distraindo-se com algum trabalho ou lendo romances. Inicialmente, as mulheres se escondiam dos novos moradores, mas após a presença de 
danças e músicas em frente à janela dessas senhoras, elas se renderam a tais eventos noturnos (p. 94). As mulheres demonstravam o seu prazer batendo as mãos e dançando sob o som de seus pequenos tambores, acompanhados de um canto agradável. Elas foram se acostumando tanto com os estrangeiros a ponto de deixarem as janelas abertas mesmo durante o dia, de sorte que do terraço dos viajantes, mais baixo, era possível ver tudo o que se passava nos apartamentos das mulheres.

$\mathrm{O}$ viajante pôde verificar que ali havia quatro mulheres, dado que a mais velha era quem cuidava da casa. Esta moça não possuía mais do que vinte e cinco anos, era "muito bem feita", embora um pouco corpulenta. As outras eram mais jovens e uma delas não deveria possuir mais do que quatorze ou quinze anos. As três eram "pessoas muito belas", mas dentre elas uma se destacava aos olhos do francês. Ela possuía o cabelo arranjado em fitas, vestia-se com um tecido de seda e ficava na janela, fazendo-se notar. Ela passava a mão sobre os seus braços, mostrando até o cotovelo, e exibia com os dedos "muitos atos de gentileza", o que era considerado neste país "marcas de consideração e de amizade" (LA ROQUE, 1716, p. 96). Por fim, ela apareceu de novo na mesma janela, acompanhada de uma menina de seis ou sete anos, sempre com as suas melodias alegres.

Os contatos com a jovem moça continuaram a ponto de Jean de La Roque fazer aportar em sua casa uma cabine da China com várias "pequenas curiosidades" e exibir para ela. Depois disso, a filha desta moça - acompanhada de uma escrava - faria uma visita ao viajante, episódio que o levou a presentear a sua vizinha com um pote de 
cravo-da-índia. Depois de alguns dias, a moça, muito grata pelo presente, retribuiu a gentileza oferecendo a $\mathrm{La}$ Roque uma "pequena flor branca muito estimada na Arábia", cujo odor era parecido ao do jasmim da Espanha. $\mathrm{O}$ viajante pôde conhecer de perto a casa onde viviam estas mulheres no momento em que elas voltavam da cidade após fazerem as suas visitas. $\mathrm{O}$ francês as encontrou presas em um vestíbulo e as cumprimentou. Mas, quando o senhor árabe chegou, fez com que elas se retirassem rapidamente (LA ROQUE, 1716, p. 99).

É certo que os eventos ocorridos nesta casa se tornaram conhecidos do governador de Muhāa, pois, em uma conversa entre ele e o viajante francês, o governador falara a La Roque sobre os estranhos costumes dos europeus em relação às mulheres. $\mathrm{O}$ espanto se referia à liberdade desfrutada pelas mulheres na Europa e a intimidade que os franceses demonstravam para com elas até mesmo na Arábia, "onde as mulheres eram observadas sem nenhum escrúpulo, do alto dos terraços, até o interior das casas" (LA ROQUE, 1716, p. 138-139). O governador, risonho, ressaltava ainda uma "história muito galante" envolvendo um dos oficiais franceses em Bayt al-Faqih [localizada no sudoeste do atual Iêmen, a $150 \mathrm{~km}$ da capital, Sana'a]. Mas Jean de La Roque não forneceu maiores detalhes para os seus leitores.

Com o sucesso comercial alcançado na primeira viagem, a "Companhia de Negociantes de Saint-Malo" [localizada no norte da França] encomendou uma nova viagem ao Iêmen, com início em janeiro de 1711. Mas a julgar pela forma como este segundo texto foi construído, é certo que Jean de La Roque não tenha participado de tal 
expedição (1716, p. 189). Isso se justifica pela narração do texto em terceira pessoa - e não mais em primeira, como ocorrera até então - e pela rapidez com o que o relato se desenvolveu: cinco páginas apenas descreviam os episódios na cidade de Muhāa durante todo o ano de 1711. A partir da saída de Muḥā para o Reino do lêmen, as descrições tornavam-se mais detalhadas, o que indica o emprego mais cuidadoso das testemunhas dos episódios relatados. Jean de La Roque informava aos leitores que havia conversado com, ao menos, dois franceses presentes nesta viagem, o que garantia um relato "razoavelmente assegurado da verdade" (p. 233).

No Reino do Iêmen, Jean de La Roque afirmava que o "nosso povo" tivera a possibilidade de ver o palácio real e buscava descrevê-lo por meio da "exata verdade" e não adornar a narrativa com "magnificências quiméricas”. Em razão deste princípio é que se poderia atestar que o palácio, embora fosse grande, era bastante simples, incluindo-se a sua estrutura, o seu mobiliário e os seus ornamentos interiores (LA ROQUE, 1716, p. 207-208). Diferentemente das descrições sobre o luxo da Corte Otomana, o autor ressaltava que a câmara real possuía apenas um assoalho ou sofá e um tecido de algodão que servia como cama. Vestindo-se com um tecido muito fino, de cor verde ou amarela, sem qualquer ornamento, tendo os joelhos e os pés nus, o próprio rei se ressentia de tamanha simplicidade.

A característica que assemelhava todos os "Príncipes do Oriente" era o "grande número de mulheres" presente na Corte, cuja soma alcançava seiscentas ou setecentas moças (LA ROQUE, 1716, p. 218). O serralho era composto 
por mulheres de diversas nações, sendo possível assegurar que as georgianas exibiam uma grande beleza e que as árabes eram muito brancas. Elas circulavam pelo castelo e pelo palácio - ambos na cidade de Mouab (localizada na atual Dhamar, a $100 \mathrm{~km}$ da capital do Iêmen) -, havendo no palácio ao menos trinta alojamentos em apartamento particular. O transporte usado por elas era o camelo, que sustentava um abrigo no qual elas se deitavam ou se sentavam. Os seus rostos eram cobertos de um tecido bem fino e muito claro.

Em Mouab, ao contrário do que ocorria em Muhāa os homens se mostravam tão ciumentos, que as mulheres pouco ousavam aparecer nos terraços das casas. O único francês do grupo que tinha se aproximado das mulheres em Mouab o fizera em virtude de sua profissão. O médico, Sr. Barbier, entrara em contato com a esposa do primeiro ministro e com a esposa de um oficial do rei para cuidar de um reumatismo sofrido por elas. Contudo, ainda que houvesse grande confiança das pacientes e de seus maridos no trabalho desenvolvido pelo médico, este jamais pôde ver o rosto das mulheres (LA ROQUE, 1716, p. 220).

A única referência ao termo harém foi feita dentro do Traité Historique de l'Origine et du Progrès du Café, que ocupa a parte final da obra de Jean de La Roque. Ele dizia que havia oficiais ou intendentes do café presentes no harém, ou "apartamentos das damas do serralho" (LA ROQUE, 1716, p. 304). O autor não estava, de fato, interessado no tema do serralho imperial, mas no comércio e na história do café. Ainda que fosse desse modo, as poucas alusões feitas à vida cotidiana das mulheres do Iêmen - tanto nas casas comuns quanto no palácio - não eram afeitas 
à sexualização desta sociedade. O seu texto, ao contrário, não poupava elogios à região visitada, à sociedade árabe $\mathrm{e}$ mesmo à religião islâmica que, embora fosse nomeada de Maometismo pelo viajante, era vista como uma prática da modéstia (LA ROQUE, 1716, p. 209).

Um ano após a publicação da obra de Jean de La Roque, vinha a público o livro referente à viagem de um dos botânicos franceses mais conhecidos dessa época. Joseph Pitton de Tournefort (1656-1708) possuía uma produção respeitável sobre botânica, quando recebeu a ordem do rei Luís XIV para viajar ao Levante, de modo que Relation d'un voyage du Levant - publicado após a sua morte - não apenas destacava o pedido real, como mencionava todos os títulos de seu autor, dentre eles, doutor em Medicina na Faculdade de Paris e Professor no Jardin $d u$ Roi e no College Royal.

No longo prefácio escrito no volume I da obra, M. de Fontenelle, "secretário perpétuo da Academia Real de Ciências”, exaltava as qualidades profissionais de Tournefort, defendendo que ele fora um excelente viajante, já que Fontenelle entendia por este termo alguém que possuía uma curiosidade destacada e um "certo dom para ver", predicados muito raros de se encontrar (TOURNEFORT, 1717, tomo 1, p. ix). Nesse sentido, a ordem para viajar pela Grécia, pela Ásia e pela África era muito apropriada, afinal, o objetivo era coletar plantas e fazer observações sobre a "História Natural e a Geografia antiga e moderna", além de descrever os "costumes, a religião e o comércio dos povos" (p. x). As informações apreendidas na viagem deveriam passar pelo crivo de um intérprete, como o próprio Tournefort deixou indicado no texto, (1717, 
tomo 2, p. 345). As cartas escritas durante a viagem foram enviadas para Louis Phélypeaux, conde de Pontchartrain, responsável por propor a viagem ao rei da França, personagem já citado quando da viagem de Jean de La Roque.

$\mathrm{Na}$ abertura da obra, no texto intitulado Projeto dessa Viagem, Tournefort tanto mostrava a sua satisfação em empreender uma viagem ao Levante para estudar "a natureza e os homens com mais certeza do que se faz nos livros" quanto indicava a necessidade de viajar com "dois homens de confiança" que pudessem partilhar com ele as "dores" de uma grande viagem (tomo 1, p. 2). Para tanto, ele escolheu o alemão Andreas Gundelsheimer (c. 16681715) e o francês Claude Aubriet (1651-1743), aquele, "um excelente médico", e este, um "hábil pintor" (p. 2). O conhecimento sobre história natural de Gundelsheimer somava-se, então, ao talento de Aubriet para registrar as plantas estudadas na viagem.

Tournefort é o primeiro homem, dentre os autores analisados aqui, que se utilizou integralmente do formato epistolar para construir a sua narrativa. $\mathrm{O}$ volume I foi dividido em doze cartas e o volume II, em dez cartas. Como já pudemos verificar em Mary Montagu e em Elizabeth Craven, essa forma de construir a narrativa deixava-se permear tanto por assuntos de interesse público quanto por temas privados, além do fato de transmitir aos leitores uma sensação de maior precisão, uma vez que as cartas registravam os acontecimentos tão logo estes ocorressem (BATTEN, 1978, p. 71). No caso de Tournefort, o leitor poderia acompanhar a viagem nos seus acontecimentos diários.

No dia 15 de março de 1701, Tournefort partia do porto de Petra em direção a Istambul. Na Carta XI, o autor 
apresentava a capital do Império Otomano como "a maior cidade da Europa" (1717, tomo 1, p. 464), não mencionando a sua também localização asiática. A primeira menção ao termo serralho ocorria sem qualquer conceituação pelo autor. Para explicar as "partes" em que estava dividida a cidade de Istambul - grafada como Constantinopla -, Tournefort informava que aquela relativa ao porto possuía uma parte mais curva e outra que se estendia "da ponta do Serralho às sete torres". Ele terminava afirmando que o ângulo de visão que se tinha ao chegar à cidade referia-se, em primeiro lugar, às sete torres, em seguida, ao Serralho, e, por fim, à Mesquita de Eyüp, construída em 1458.

Se Lady Montagu defendia que as mulheres turcas possuíam liberdade social - informação reiterada por Elizabeth Craven -, Tournefort se posicionava de outro modo em relação a essa matéria. Ele relatava que as mulheres eram persuadidas pelos seus maridos a não saírem de casa; e, para retê-las nesse espaço, eles construíam banhos e as divertiam com café. Mas isso era em vão, afinal, belos rapazes se travestiam de escravas e levavam roupas e joias para venderem às mulheres (TOURNEFORT, 1717, tomo 1, p. 473). Além disso, havia sempre a presença de mulheres judias que favoreciam as "belas paixões" das turcas. De todo modo, para o botânico, havia menos intrigas entre as turcas do que entre eles - o autor não esclarecia se a menção era aos franceses ou aos europeus. As gregas, as judias e as armênias, por sua vez, possuíam maior liberdade, contudo, elas não saíam tão frequentemente como "nossas mulheres", porque os serviços externos a casa ficavam por conta dos escravos (tomo 1, p. 474). 
A primeira conceituação deliberada que Tournefort fez sobre o serralho apenas reiterava o que já havia sido indicado de maneira difusa anteriormente: "Serralho significa um palácio" (1717, tomo 1, p. 494). O serralho em questão era o que estava localizado no Bósforo e havia sido construído por ordens do sultão Mehmet II, ou seja, tratava-se do palácio Topkapi, concluído em 1478. O botânico, todavia, não se rendeu ao tema do luxo - tão bem lembrado por outros viajantes a respeito dos palácios otomanos, como vimos no Capítulo 1 . Na sua visão, o interior do palácio não possuía nada do que "nós chamamos de soberbo e magnífico" (p. 495). Para ele, os turcos não conheciam as regras para fazer uma "boa arquitetura". As "bacias de mármore, os banhos, as fontes jorrando" eram as "delícias dos Orientais" (p. 495). Para concluir, Tournefort sugeria que o palácio fosse "colocado a baixo" e que, no seu lugar, fosse feito outro prédio a partir de um "novo modelo".

A estrutura do serralho apresentada por Tournefort assemelhava-se ao que Jean Chardin havia escrito acerca do palácio persa. Enquanto Chardin explicava a existência de três portas, sendo a última guardada por eunucos e vedada aos olhares externos, Tournefort notava a construção de duas Cortes - defendidas por cinquenta Capigis, ou porteiros -, alertando que a partir da segunda Corte e somente com autorização é que se poderia passar ao "interior do Serralho". Sobre esse assunto, o autor concluía que era tudo o que um estrangeiro poderia ver no serralho, pois "para penetrar mais adiante, a curiosidade custaria muito caro" (TOURNEFORT, 1717, tomo 1, p. 499). Serralho era também o termo usado para indicar os 
alojamentos no alto da cidade de Pera em que ficavam crianças escolhidas de famílias gregas. Após se converterem ao islamismo e serem preparadas em exercícios convenientes, essas crianças tornavam-se oficiais do Grão-Senhor otomano (TOURNEFORT, 1717, tomo 1, p. 508).

Tournefort - como também fez Chardin - ressaltou a origem das mulheres tomadas como cativas de guerra e vendidas posteriormente ao sultão e aos baxás otomanos. Manifestando um tom irônico, o autor afirmava que "nada é tão agradável quanto ver chegar incessantemente da Hungria, da Grécia, de Candia, da Rússia, de Mingrélia e da Geórgia uma quantidade prodigiosa de moças destinadas ao serviço dos turcos" (tomo 1, p. 515). Eram essas jovens estrangeiras que se tornavam esposas do sultão, dos baxás e de outros "grandes senhores" do império. O fato de serem conduzidas ao serralho não garantia melhor sorte a elas. É certo que uma mulher pobre poderia se tornar uma sultana - lembrava o autor -, mas uma vez no palácio, elas eram negligenciadas pelo sultão. Após a morte deste, as jovens seriam fechadas pelo "resto de seus dias" no "Velho Serralho", onde elas seriam tomadas de langor, a menos que fossem procuradas por algum baxá (p. 516). Tratava-se, pois, de um crime que as mulheres chorassem a morte do sultão ou de seus filhos no serralho, local onde passaria a residir o novo imperador (p. 516).

No volume II da obra, Tournefort manteve o mesmo padrão estrutural usado no primeiro volume e não se dedicou a escrever uma carta especialmente devotada a caracterizar o serralho de Istambul. No lugar disso, as observações sobre o serralho se espalharam pelo texto. $\mathrm{Na}$ Carta XIII, o autor afirmava que "não há Príncipe que seja 
servido mais respeitosamente do que o Sultão" (1717, tomo 2, p. 8) - este "mestre do mundo" -, explicando que o serralho era constituído por cinco grupos: os Eunucos, os Icoglans, os Azamoglans ${ }^{43}$, as Damas e os Mudos (p. 8). Além deles, podiam-se acrescentar os anões e os bufões, mas estes não mereciam compor outro grupo, de acordo com Tournefort.

O autor se dedicou na sequência a explicar as características e as funções de cada grupo no palácio imperial. Contudo, apontarei apenas as observações diretamente relacionadas à conceituação do termo "serralho" e ao grupo das "Damas". Na sua definição de serralho, Tournefort afirmava que esse lugar era "uma República, cujos indivíduos têm as suas leis e os seus costumes. Aqueles que comandam e aqueles que obedecem não sabem o que é liberdade e não têm qualquer contato com os habitantes da cidade" (1717, tomo 2, p. 12). Seguia-se a isso o comentário sobre a escravidão dos prazeres a que estava submetido o sultão e o estado de languidez que reinava no palácio. Para além do tema da reclusão do serralho e da lascívia do sultão, esse trecho do livro guarda uma aproximação notória com a definição de serralho de Louis Deshayes de Courmenin, citada no Capítulo 1. Tal fato nos permite pensar, uma vez mais, nas apropriações que os viajantes faziam de narrativas já publicadas.

No serralho, havia eunucos brancos e negros, cujas atribuições eram assim divididas: aqueles ficavam a serviço

43 Os İç Oğlan eram jovens oficiais do palácio, já os Azamoglans eram crianças encarregadas de funções "mais baixas e mais penosas" no serralho. Ver <www.cnrtl.fr/definition/Azamoglans $>$. 
do príncipe e estes eram os responsáveis por guardar os apartamentos das mulheres. Uma vez que esses "pobres coitados" - como os descrevia Tournefort - eram castrados, somente lhes era possível "lançar os olhos sobre as mulheres" e se colocar como sentinelas em frente à porta de seus quartos (1717, tomo 2, p. 9). Os eunucos negros desfrutavam a "honra" de aparecerem diante das mulheres no serralho porque eles não se deixavam tomar nem pela tentação nem pelo ciúme.

Contudo, tamanha insensibilidade dos eunucos era negada no item "As Damas do Serralho", afinal, para o autor, a beleza de tais mulheres servia tanto para divertir o sultão quanto para enfurecer os eunucos (1717, tomo 2 , p. 20$)^{44}$. Aqui Tournefort voltava a repetir o episódio de isolamento dessas mulheres no "Velho Serralho" quando da morte do sultão. O acréscimo feito era apenas para indicar que as moças mais jovens poderiam, por vezes, ser reservadas ao novo sultão ou então poderiam se casar com algum baxá (tomo 2, p. 20). Tais mulheres eram vistas por ele como as "escravas menos infelizes que existem no mundo", mas ainda assim a liberdade era sempre preferível a qualquer "felicidade frágil" (tomo 2, p. 20) (5) $^{4}$.

A crítica mais contundente de Tournefort referia-se ao modo como se dava a prática médica dentro do serralho, e isso se devia possivelmente ao seu conhecimento nessa matéria. Ele iniciava esse assunto com uma exclamação: "o que dizer de um lugar onde se admite apenas o

44 É a mesma afirmação usada pela Encyclopédie, já citada (DIDEROT; D'ALEMBERT, 1765).

45 Essa afirmação também foi registrada na Encyclopédie, como foi citado no início deste capítulo. 
primeiro Médico do Príncipe para ver as mulheres agonizando!" (1717, tomo 2, p. 20). Ele continuava seu julgamento afirmando que o médico não deveria ver as mulheres nem ser visto por elas, de modo que o pulso da paciente poderia apenas ser tomado através de uma gaze ou de outro tecido. Caso o médico pedisse para examinar a extremidade da língua ou precisasse tocar em qualquer parte do corpo de uma paciente, ele seria apunhalado.

Tournefort indicava, em seguida, que as suas observações provinham de sua própria experiência no serralho, uma vez que ele afirmava ter atravessado o local onde ficavam os apartamentos das mulheres. Esses apartamentos eram feitos como "os dormitórios de nossos religiosos", e em cada porta era possível encontrar um "braço coberto de gaze que avançava por um orifício feito com tal intenção" (1717, tomo 2, p. 21). Ele informava aos leitores que, inicialmente, pensou se tratarem de braços de madeira ou de cobre destinados a clarear a noite. A sua surpresa foi grande quando foi advertido de que aqueles braços pertenciam a pessoas.

Logo na sequência, o autor colocava em xeque a tese de que mulheres judias podiam caminhar livremente pelos apartamentos femininos para ali venderem joias. Sobre isso, Alain Grosrichard - escrevendo a respeito da peça Bajazet, de Jean Racine (1639-1699) - perguntava-se: “o que sabem aqueles que Racine considera como fontes fidedignas [...], tomando como pretexto a confidência de uma velha judia introduzida por breve momento nos aposentos da criada de uma sultana?" (1988, p. 163). Tournefort explicava que as judias não avançavam além de certa sala onde se fazia tal comércio, e isso ocorria somente depois 
de terem sido examinadas pelos eunucos. O autor, contudo, entrou em contradição mais adiante, quando afirmou que as "escravas judias" entravam a todo o momento nos apartamentos das turcas (1717, tomo 2, p. 94). Se um homem fosse surpreendido travestido de mulher, seria enforcado naquele momento; já uma cristã seria muito mal recebida (TOURNEFORT, 1717, tomo 2, p. 21).

As mulheres residentes nos apartamentos reais, chamadas de Sultanas por Tournefort, saíam eventualmente de seus apartamentos e passeavam de carruagem, não antes de tais veículos serem fechados "com o mesmo cuidado com que se conduzem os prisioneiros" (1717, tomo 2, p. 74). Durante os três dias em que essas mulheres permaneciam próximas ao Grão-Senhor, apenas eunucos negros poderiam servi-lo. As visitas de uma senhora para a outra somente ocorreriam depois de elas ofertarem os seus "votos" ao imperador. Lembremos que a baixa frequência das saídas feitas pelas mulheres do serralho também foi notada por Jean Chardin em sua viagem à Pérsia.

Uma vez que as mulheres turcas viviam em "prisões", a sua liberdade se dava no momento em que elas fossem orar nas mesquitas. Era nestes lugares que as muçulmanas tinham a companhia das judias e onde os estrangeiros poderiam vê-las. É neste trecho que Tournefort inseria o tema do amor e do adultério. O amor "engenhoso" não foi tão discutido pelo autor, diferentemente do adultério, que foi descrito como um comportamento que levava a uma punição rigorosa. Se o marido traído tivesse a "alma vingativa”, ele fecharia a mulher em um saco cheio de pedras e a atiraria à água. Mas a maior parte das mulheres sabia contornar a situação, e não morria afogada. Já o amante 
era condenado a andar nas ruas durante um ano, portando uma coroa de tripas e uma gravata de tecido similar. Ele levaria ainda chicotadas e pagaria uma multa proporcional aos seus bens (TOURNEFORT, 1717, tomo, p. 95).

A liberdade também poderia ser desfrutada nos banhos públicos. As mulheres ficavam muito felizes quando tinham a permissão de irem a este lugar. A maior parte delas - sobretudo as que possuíam marido rico - tinha o banho em sua própria casa e não desfrutava da liberdade de sair. Era nos banhos públicos, de outro modo, que as mulheres se entretinham e passavam horas mais agradáveis do que nos seus apartamentos (TOURNEFORT, 1717, tomo 2, p. 88). A assiduidade com que as mulheres se banhavam, e, portanto, o seu asseio, chamaram a atenção do francês a ponto de ele assinalar que essas moças iam ao hammām duas vezes por semana e não tinham qualquer pelo ou sujeira no corpo.

Se Tournefort não deixou registrada a fonte de suas informações sobre o serralho, ele a indicou no momento em que descreveu as mulheres nos banhos. Dizia ele que, de acordo com relatos de franceses de Istambul e de Esmirna [no sudoeste da atual Turquia], as mulheres turcas iam aos banhos com muita liberdade e eram em geral "belas e bem feitas". A sua pele era fina, os seus traços, regulares, o pescoço, admirável, e quase todas tinham os olhos negros; muitas eram inclusive de uma "beleza perfeita". O autor elogiava, por fim, quão naturais eram essas mulheres, já que não usavam artifícios para corrigirem os defeitos que com o avanço da idade apareciam. O próprio sangue das "mulheres do Levante" foi tomado como mais puro (TOURNEFORT, 1717, tomo 2, p. 94). 
Diferentemente das mulheres fechadas em seus apartamentos, havia em Istambul aquelas que Tournefort chamou de "mulheres devassas e perdidas", em uma referência às prostitutas e não às mulheres turcas de forma ampla. Tais mulheres andavam nas ruas mostrando tudo o que a modéstia ordenava esconder e ganhavam a vida com tal função. O restante das mulheres turcas, de outro modo, nunca exibia qualquer parte do seu corpo em público, nem mesmo o seu rosto - que era coberto por um lenço bem fino, o que levou o autor a encará-las como mulheres "presas" (TOURNEFORT, 1717, tomo 2, p. 93). A ausência de liberdade era certamente a marca por excelência daquelas que viviam no serralho imperial otomano.

Com o adensamento das informações sobre o Levante dentre os europeus, mais viajantes se dedicavam a estudar as línguas das sociedades árabes ou islâmicas. É neste cenário que encontramos o viajante Johan [Jean] Otter (1707-1748), sueco exilado na França que havia estudado o árabe, o turco e o persa, tornando-se professor de árabe em Paris, em 1746, e que em 1748 foi escolhido como membro da "Académie Royale des Inscriptions \& Belles-Lettres". Foi inclusive com a ajuda de um ministro francês, em Estocolmo, que Otter se converteu ao catolicismo (SOHRABI, 2005, p. 640). Por abjurar o luteranismo, ele seria obrigado a abandonar a Suécia (RIOTTOT apud OTTER, 2010, p. 9). Otter viajou tanto para o Império Otomano quanto para a Pérsia, e publicou a sua Voyage en Turquie et en Perse: avec une relation des expéditions de Tahmas Kouli-Khan em dois volumes, no ano de 1748. O texto recebeu tradução para o alemão em 1781. Otter seria nomeado cônsul francês na cidade de Basrah 
[no atual Iraque] em 1742, permanecendo dez anos no Levante.

O livro foi dedicado ao conde de Maurepas, ministro e secretário de Estado francês, que havia encomendado a viagem a Jean Otter. Na sua dedicatória ao marquês, o viajante explicava que pretendia prestar esclarecimentos sobre a "História do Oriente", respondendo às intenções apresentadas por Maurepas (OTTER, 1748, vol. 1, p. ii). Em virtude das circunstâncias políticas da viagem, a obra contava com a "Aprovação e Privilégio do Rei" [informação estampada na capa] e ficaria depositada na "Biblioteca do Rei". No Prefácio, Otter elucidava ainda os seus métodos de coleta de informações sobre a Geografia e a História do Levante. O autor informava a seus leitores que havia consultado os "melhores geógrafos orientais", cujas obras haviam sido examinadas na própria "Biblioteca do Rei", além de pesquisado "Memórias manuscritas" e conversado com pessoas "muito instruídas". As "testemunhas oculares" também haviam sido incorporadas às suas investigações (OTTER, 1748, vol. 1, p. iv-v).

É no Prefácio também que Jean Otter deixava indicado o seu conhecimento a respeito da literatura de viagem produzida até o momento. A sua intenção era seguir uma rota não mencionada por nenhum outro viajante. $\mathrm{Na}$ sequência, o autor inseria uma informação inédita dentro do corpus narrativo examinado aqui: ele justificava a necessidade de operar mudanças na ortografia dos nomes citados em seu texto, alegando que a ignorância ou mesmo a negligência eram responsáveis por introduzir "nomes corrompidos" nos livros de viagem. Uma das palavras corrigidas era caravansera que deveria ser substituída por 
kiervanseraï [caravançará], cujo significado era alojamento para viajantes (OTTER, 1748, vol. 1, p. 38). A familiaridade com tais erros impedia que se pronunciasse o contrário sem "ofender os ouvidos" (p. vi-vii).

A viagem de Otter com destino a Istambul - chamada de Constantinopla - iniciou-se em 27 de janeiro de 1734 em Paris, sob ordens do já citado conde de Maurepas. Após o susto inicial provocado por uma tempestade, o navio mercante chegaria à capital do Império Otomano no dia 10 de março. Já no capítulo 2, havia uma menção aos "Serralhos", colocados ao lado de mesquitas e fontes; todos entendidos como exemplos de uma "arquitetura singular" (OTTER, 1748, vol. 1, p. 7). Essa ideia de beleza, contudo, perdia-se tão logo se entrava na cidade, pois o autor reclamaria das ruas estreitas e das casas de madeira. $\mathrm{O}$ viajante também questionaria a imagem pejorativa sobre os turcos - observação que já lemos em Henry Blount. Como escrevia Otter, "os turcos não são tão insociáveis, nem tão bárbaros quanto as pessoas comuns os imaginam" (OTTER, 1748, vol. 1, p. 8-9).

No capítulo 3, Otter dedicou uma nota de rodapé ao termo Seraï des Itchouglans, palavra para designar $\dot{I}_{c}$ Oğlan, ou jovens meninos que eram tomados como servos pelos otomanos. Na sua definição, esse espaço consistia em um "Palácio onde os Pajens do Grão-Senhor são aprendizes" e de onde eram escolhidos aqueles que serviriam no "grande Serralho" (OTTER, 1748, vol. 1, p. 10). Do mesmo modo, era feita uma ressalva em torno da palavra harém:

Harém é uma palavra árabe que significa algo sagrado ou proibido: é usada primeiramente para Meca 
e para Medina; em segundo lugar, para o espaço da casa onde estão as mulheres; e em terceiro lugar para as próprias mulheres. Comete-se geralmente um erro quando se usa o segundo significado desta palavra para se referir ao Serralho, que significa apenas Palácio (OTTER, 1748, vol. 1, p. 16).

O primeiro significado anotado por Otter remete ao caráter sacro das cidades de Meca e de Medina. Por serem as cidades onde foram reveladas as mensagens de Deus ao profeta Muḥammad, elas são conhecidas em árabe como dois "Haramaīn", ou seja, aquilo que é sagrado (BOOTH, 2010 , p. 5). Nesses locais, não é permitido matar - a não ser animais nocivos ou perigosos -, além de ser vedada a presença de não muçulmanos (GLASSÉ, 2002, p. 170). A palavra, portanto, não possuía originalmente um significado de gênero, entretanto, seria usada com tal intenção. $\mathrm{Na}$ história das práticas cotidianas da comunidade islâmica, a palavra harém passou a ser empregada não somente com o valor de divisão espacial, mas principalmente no sentido de reclusão feminina. Voltarei a esta discussão no Capítulo 5.

Além do aspecto sagrado e da caracterização feminina, Otter ressaltava a definição imprópria dos aposentos femininos: aquela que fazia uso do termo serralho para indicar este lugar. Como já pudemos notar em outras narrativas de viagem, o uso dos termos serralho e harém como equivalentes era uma prática comum. Do mesmo modo, havia quem empregasse a palavra serralho para indicar apenas o palácio imperial, e harém, com o valor de espaço exclusivamente feminino. Ao longo de sua narrativa, Otter manteve a distinção entre essas palavras, nomeando o palácio imperial de serralho. 
Seguindo esses pressupostos, Otter utilizava o termo harém no texto corrente com o sentido de espaço feminino. No dia em que ele aceitou o convite para tomar café na casa do mula - estudioso islâmico que lhe ensinava a língua turca -, ele percebeu que havia mulheres que o olhavam através da cortina. Apercebendo-se disso, o mulā saiu bruscamente do cômodo em que estavam e fez com que as mulheres entrassem no harém, "onde ele as trancou" (1748, vol. 1, p. 24). Na sua volta, o viajante mostrou o seu descontentamento com a privação de um "prazer tão inocente" para aquelas mulheres. O mulä, tomando um ar sério, respondeu que essa era uma prática estabelecida entre eles e que, caso se permitissem que as mulheres circulassem entre os homens nas casas, isso provocaria uma série de desordens. Otter contra-argumentou, dizendo que as mulheres na Europa eram "doces e razoáveis”. O mulā, contudo, encerrou o assunto, afirmando que "as mulheres são iguais em toda parte", e agradecia a Deus por ter permitido a ele nascer em um país onde esse comportamento era permitido (p. 25).

No dia 24 de novembro de 1736, Otter deixava Istambul e partia em direção à Pérsia. Neste lugar, o autor notava as diferenças de costumes entre os turcos e os persas, informando que estes sempre levavam as suas mulheres para a guerra ou em suas viagens; hábito que não se notava entre os turcos (1748, vol. 1, p. 97). Após elogiar as diversas habilidades de tais mulheres - como o fato de tocarem instrumentos musicais, terem belas vozes ou bordarem com perfeição -, o viajante sueco notava que um eunuco conduzia vinte e quatro mulheres para o harém 
de Nadir-Shah (c. 1688-1747) ${ }^{46}$ que governou a Pérsia entre 1736 e 1747. Além destas, uma dezena de outras mulheres comprada por Ibrahim-Khan, governador de Tauris [atual Tabriz, no norte do Irã], estava sob a guarda de um armênio. Em 1739, o filho mais velho de Nadir-Shah, Rizā Qulī Mirzāa após pensar que o seu pai estivesse morto na Índia, buscou se assegurar do trono ${ }^{47}$. Para tanto, foi persuadido por Muḥammad Hụssain Khān, da tribo Qājār, a assassinar o Shāh anterior da Pérsia, Țahmāsp II, e os seus dois filhos que estavam presos em Sabzevār [cidade situada no nordeste do atual Irã]. É provável, contudo, que o próprio Qājār tenha se incumbido da ação. Abdul Sabahuddin, todavia, afirma que teria sido o próprio Nadir-Shah quem teria assassinado Țahmāsp II e os seus filhos (2008, p. 43). Otter assegurava que Mirzā não teria se esquecido nem mesmo das mulheres grávidas do harém do Shāh Ḥussain, pai de Ṭahmāsp II, uma vez que não queria deixar vivo ninguém da família deste governante safávida.

Apesar de citar o harém, o viajante sueco não corroborou a ideia que relacionava a luxúria ao harém de Shāh Hussain - cujo governo se estendeu de 1694 a 1722 -, mas é possível encontrar esse tipo de referência em outro viajante da época. Jonas Hanway (1712-1786), viajante inglês, escreveu um longo texto sobre a história política da Pérsia e não se esqueceu de mencionar algumas características reprováveis no Shāh Ḥussain. $\mathrm{Na}$ sua visão,

${ }_{46}$ Nadir-Shah teria somado 33 mulheres em seu harém (SABAHUDDIN, 2008, p. 41-44).

47 As tropas persas deixaram a Índia no início de maio de 1739, levando consigo milhares de "garotas indianas [tanto hindus quanto muçulmanas] e um grande número de garotos como escravos" (SABAHUDDIN, 2008, p. 43). 
tratava-se de um homem honesto, mas "tão excessivamente indolente e imoderadamente viciado em mulheres e em vinho quanto absolutamente incapaz de governar" (HANWAY, 1754, p. 103). Na literatura contemporânea, é possível encontrar a informação de que tanto o Shāh Hussain quanto o Shāh Sulayman - que governou entre 1669 e 1694 - eram homens "voluptuosos" (CURTIS; HOOGLUND, 2008, p. 21).

Algumas páginas adiante, Otter retomou o assunto sobre a vida política do Shāh Hussain para mencionar a sua inabilidade em comandar o império. Sendo assim, afirmava o viajante, ele se deixou "governar pelos eunucos", que já possuíam suficiente crédito desde o governo de seu pai, o Shāh Sulayman (OTTER, 1748, vol. 1, p. 245-246). A política persa neste momento não era engendrada, portanto, pelo mérito, mas por uma série de agraciações, uma vez que o Shāh costumava oferecer presentes para preservar os seus eunucos, ainda que muitos não permanecessem no governo. A Índia também não ficou imune às críticas de Otter. Para ele, a desordem que imperava nesse momento se devia à displicência do vizir Qamar-ud-din Khan que estava "entregue ao vinho, às mulheres e ao prazer da caça”" (p. 337). À exceção do Ministro de Estado, Nizam ul-Mulk, "os outros Senhores da Corte, mergulhados na devassidão, passam o seu tempo com mulheres ou com bufões" (OTTER, 1748, vol. 1, p. 342).

As experiências de Otter em relação ao harém não se resumiam, contudo, apenas ao conhecimento da história da dinastia safávida ou do Império Mogol. O viajante sueco, assim como o médico inglês William Lempriere, havia tido a oportunidade de entrar em um harém. Otter 
explicou que comprara uma caixa de remédios em Istambul para uso próprio. Mas quando estava na Pérsia havia sido tomado por médico em vários momentos. Em uma dessas ocasiões, um armênio - que trabalhava no harém de Nadir-Shah e de Ibrahim-Khan - pediu a ele que ajudasse a "mais bela e a mais querida das escravas", que não comia nem dormia já havia alguns dias (OTTER, 1748, vol. 1, p. 99). Otter insistiu no fato de não ser médico, mas o armênio não acreditou e pediu que o viajante receitasse remédios para a moça. Para se livrar daquela situação, o viajante respondeu que não poderia prescrever remédios sem ver a doente. Otter foi, então, conduzido ao harém e teve "a liberdade de examinar a doente", mas na presença do armênio. Ele prometeu os remédios para a paciente e se retirou (p. 99).

Logo em seguida, um eunuco chegou ao harém e chamou Otter, dizendo que precisava informá-lo sobre um assunto importante. O eunuco disse ao viajante que temia pela vida de uma mulher doente no harém. Novamente, o viajante teria dito que não era um médico, mas diante do pedido do eunuco, Otter seguiu em direção à sua "paciente". Então,

um momento depois, ele [o eunuco] me levou para uma sala escura cujas janelas haviam sido rigorosamente fechadas. A paciente havia sido colocada atrás de uma cortina, e uma única lâmpada no canto da sala emitia uma luz fraca. O eunuco estava sempre com os olhos fixados sobre mim, e, tendo os meus [olhos] fixados sobre ele, eu falava com a paciente (OTTER, 1748, vol. 1, p. 100).

Após a resposta da paciente - que Otter não deixou registrada -, o viajante respondeu ao eunuco que ele não 
era "suficientemente instruído" nos conhecimentos médicos e que, afora examinar o pulso e o rosto da paciente, ele não poderia lhe receitar remédios. Diante do desespero de um homem que testemunhava a cena, o viajante retificou a sua afirmação, dizendo que sabia a natureza da doença e que daria um remédio para a moça. Para Otter, a doença das duas mulheres no harém havia operado muitas mudanças nelas, porque ele não notara em nenhuma das duas qualquer traço de beleza. De todo modo, o viajante entregou uma quantidade de quinino com febrífugo (antipirético) e "elas foram curadas" (OTTER, 1748, vol. 1, p. 101).

O volume II da obra descrevia o retorno de Otter para a Europa. Ele havia permanecido mais de vinte meses na Pérsia e no dia 12 de abril de 1739 despedia-se de Isfahan. A sua chegada a Paris ocorreu em janeiro de 1744. Apesar da teorização em torno do conceito de serralho e harém esboçada no volume I, o autor não se dedicou a descrever tais termos no volume II. De outro modo, um tema de interesse aqui foi mencionado por Otter logo no início da obra: as liberdades sexuais nas terras do Levante. Passando pela cidade de Saḥneh [no atual Irã], Otter relatou um evento que ocorria neste lugar. Depois de beberem e comerem, e tendo-se apagado as luzes, homens e mulheres ficavam em silêncio e trocavam de lugar para não serem reconhecidos. "Nessa confusão, cada homem toma uma mulher - a primeira que se encontra sob sua mão - e se permite toda sorte de liberdades com ela" (OTTER, 1748, vol. 2, p. 15). Em virtude disso, Otter denominava esta situação de "deboche" e não de festa. A descrição, contudo, não se referia aos muçulmanos, ou como escrevia o autor, 
maometanos. Pois, para estes, tratava-se de uma cena de horror, sendo os seus personagens vistos como "criminosos dignos de morte" (p. 15).

Otter possuía uma visão favorável sobre os muçulmanos e especialmente sobre as características da sociedade persa. Além de não mencionar qualquer elemento que relacionasse os muçulmanos à lascívia, o viajante sueco dedicou-se a elogiar os persas como pessoas "muito hábeis", afinal, este povo era bem-sucedido nas ciências, nas artes e em tudo o que eles empreendiam. Além disso, eles eram justos e polidos em relação aos estrangeiros. O seu gosto pela boa comida e pelo vinho era notório, assim como a sua afeição pelo "luxo" e pelo "fausto" (OTTER, 1748, vol. 2, p. 211). Seguindo tais parâmetros, o seu entendimento sobre o prazer não poderia ser mais sutil. Para descrever esta sensação, o autor comparou o “deleite da alma” experienciado por um sufi ao prazer do corpo que, em estado de calor, é refrescado por um leque.

As sutilezas ao modo poético de Jean Otter não encontram sombra na obra do último autor a ser lido neste capítulo. Constantin François de Chassebœuf (17571820), mais conhecido como conde de Volney [contração de Voltaire e Ferney], escreveu a sua narrativa de viagem no final do século XVIII, mais precisamente em 1787. $\mathrm{O}$ título era Voyage en Syrie et en Egypte, pendant les années 1783, 1784 et 1785: avec deux cartes géographiques et deux planches gravées, représentant les ruines du Temple du Soleil à Balbek, et celles de la ville de Palmyre, dans le désert de Syrie. Nesse mesmo ano, uma edição revista e corrigida seria publicada, texto que usarei aqui.

Como pudemos acompanhar até o momento, os viajantes-autores, em maior ou em menor medida, lidavam 
com o problema da veracidade das narrativas de viagem anteriores e não raras vezes asseguravam aos leitores que o seu texto era mais bem comprometido com a verdade do que as obras que lhes precediam. Sobre isso, Volney demonstrava a sua posição teórica a respeito das narrativas logo na capa de seu texto. A afirmação abaixo do título era: “eu penso que o gênero das viagens pertence à História e não aos Romances”. Entre os séculos XVII e XVIII, não apenas as reflexões sobre as diferenças literárias entre História e Ficção se intensificaram, como mais autores se dedicavam a pensar nas bases da escrita historiográfica ${ }^{48}$.

A História era, de fato, um dos interesses de Volney, mas a seu lado figuravam os estudos de ciências naturais e de línguas antigas. Para alguém apaixonado pelo conhecimento, viajar parecia ser o melhor método para aprender. As condições favoráveis para uma viagem estavam dadas: o desejo por conhecer outros povos somava-se ao dinheiro para financiá-la, uma vez que Volney havia recebido uma pequena herança no valor de 240 libras. Restava, então, decidir o destino da viagem. Se os Estados vizinhos pareciam-lhe muito conhecidos, a "América nascente e os Selvagens" o tentavam. A decisão, contudo, pendeu para as regiões islâmicas. Ele alegava que a Síria e, sobretudo, o Egito, pareciam ser lugares próprios às observações políticas e morais das quais ele gostaria de se ocupar.

48 No século XVI, René Descartes (1596-1650) colocava em questão o ceticismo histórico, mas não estabelecia métodos para a crítica histórica. Giambattista Vico (1668-1744), por sua vez, elencava certas regras de método, além de cinco fontes de erros. David Hume (1711-1776) e Voltaire (1694-1778), de outro modo, buscavam construir uma historiografia pautada em "secularizar cada setor da vida humana". Sobre esta discussão, ver Sharma, 2005, p. 92-114. 
A justificativa para essa tese vinha em seguida. Era nestes países que havia nascido "a maior parte das opiniões que nos governam; é daí que surgiram as ideias religiosas que influenciaram tão poderosamente a nossa moral pública e particular, as nossas leis, toda nossa condição social" (VOLNEY, 1787, tomo 1, p. vi). O seu interesse era pesquisar a permanência e a mudança do espírito e dos costumes, além de observar a influência do clima, os efeitos do governo, ou seja, "julgar pelo estado presente o que foi o estado dos tempos passados" (p. vii). Para desempenhar a contento tal projeto, Volney se pôs a estudar a língua árabe, cujo aprendizado se iniciou em 1780 no Collège de France (GAULMIER, 1980, p. 32). Para ele, sem o conhecimento da língua não era possível apreciar o "gênio e o caráter de uma Nação". Além disso, o viajante precisava de tempo, pois somente assim poderia observar os objetos com cuidado e se assegurar de sua justeza.

A viagem começou em fins de 1782, quando Volney partiu para o Egito. O viajante permaneceu por sete meses no Cairo, e reclamou tanto da dificuldade em percorrer o interior do país quanto da falta de assistência para aprender a língua árabe. Ao final da sua jornada, o autor afirmava não entender de onde vinha o entusiasmo dos viajantes pelo Egito, pois a sua própria experiência não lhe havia revelado as causas secretas. Após esse período no Egito, ele seguiu para a Síria, onde viveu em um "convento árabe" entre os drusos e onde pôde melhor aprender o árabe. A sua permanência na Síria durou um ano, tempo que ele empregou em percorrer o país. A decisão por publicar o seu livro deveu-se à crença de que as viagens para tais regiões eram difíceis de serem empreendidas e os relatos daí 
derivados eram raros e imperfeitos. A publicação dos dois volumes da obra teve o apoio do rei da França.

Não fugindo à regra dos outros viajantes-autores já citados, Volney informou os seus leitores, ainda no Prefácio, que, no tocante à Síria, ele apenas se permitiria falar sobre aquilo que havia visto. Mas desejando completar o quadro descritivo sobre esta província - "para a satisfação dos leitores" -, ele não se furtaria em usar observações estrangeiras, quando pudesse por analogia confiar na sua veracidade (VOLNEY, 1787, tomo 1, p. x). A sua narrativa buscaria, então, o "exame dos fatos", enaltecendo "um amor imparcial da verdade" (p. x). A mesma postura pode ser verificada no item Aprovação que se encontra ao final do Tomo II. O examinador do texto alegava que a obra interessava aos leitores tanto pelos "detalhes curiosos" que continha quanto pelo "tom de verdade" com o qual havia sido escrita.

Elemento importante dessa discussão era apontado na sequência, quando Volney afirmava ter recusado qualquer cenário de imaginação, apesar de não ignorar os benefícios da ilusão para a maior parte dos leitores. Eis que a frase ressaltada na capa do livro era enunciada novamente: a narrativa de viagem vinculava-se à História e não ao Romance. Portanto, ele não representaria os países de forma mais bela do que lhe pareciam, nem retrataria os homens melhores ou mais perversos do que tinha visto. Afinal, ele não havia recebido nem benefícios nem ultrajes para agir desta maneira (VOLNEY, 1787, tomo 1).

O livro de Volney foi dividido em dois tomos e, dentro deles, em quatro partes. A primeira e a segunda parte se referem ao estado físico e político do Egito, enquanto as 
partes três e quatro descrevem o estado físico e político da Síria. Uma vez que o autor recusava a metodologia comumente usada nos textos de viagem, qual seja, a de indicar os eventos relativos ao itinerário da viagem, assim como os pormenores das "aventuras pessoais" (1787, tomo 1, p. xi), a sua narrativa buscou assentar-se nos temas citados, ressaltando com maior atenção o comportamento do viajante diante de uma sociedade que lhe era desconhecida.

$\mathrm{O}$ autor ia além e indicava a dificuldade em se fazer a apreensão dos objetos para fixá-los no texto. Tal apreensão se tornava mais aguda quando o retrato a ser feito era o de uma sociedade estrangeira. Nesse caso, a imaginação, não encontrando termos de comparação já existentes, era obrigada a "assemelhar membros dispersos para compor um novo corpo" (VOLNEY, 1787, tomo 1, p. 1-2). Ele admitia que nesse trabalho era muito difícil não confundir os traços e alterar as formas. Portanto, era preciso se perguntar sobre a diferença entre a cópia e o modelo original e o caráter de novidade que se imprimia naquela. Este era o caso de um europeu que chegava à Turquia, termo usado por ele para se referir ao Império Otomano: a variedade dos objetos o deslumbrava, e tudo o que ele havia pensado se dissolvia; ele se entregava, então, aos "sentimentos da surpresa e da admiração" (p. 2).

Nos extensos volumes de sua obra, Volney não dedicou uma linha sequer a explicar aos seus leitores o que entendia por harém ou serralho. $\mathrm{O}$ termo harém foi empregado uma única vez ao longo dos capítulos, mas embora estivesse em um formato destacado em relação às outras palavras do trecho [Harem], o autor se resumiu em citá-lo como um espaço que recebia suprimentos, tais como 
faixas e tecidos, fornecidos por negociantes do Cairo. Esta informação foi usada com uma intenção muito particular. A esposa de um desses negociantes havia dito a Volney que as mulheres dos mamelucos não eram verdadeiramente bonitas. Falava-se muito sobre a sua beleza, mas os europeus - que não as tinham visto - não poderiam ser tomados como testemunhas. $\mathrm{O}$ autor concluía que essas mulheres eram ainda mais invisíveis do que as outras e era, sem dúvida, a este mistério que se devia a ideia de sua beleza.

Volney utilizou somente uma vez o termo serralho no Tomo I e não se deteve em explicá-lo. O uso feito por ele nos sinaliza apenas que a relação estabelecida entre serralho imperial e luxo era bastante recorrente nas observações dos viajantes. $\mathrm{O}$ excesso de despesas com o serralho indicava a política arbitrária do sultão otomano e o estado de submissão vivido pelos súditos de tal "despotismo militar” (VOLNEY, 1787, tomo 1, p. 98). Para elucidar esse excesso de despesas, o autor citou o exemplo da pelica, informando que esse produto estava em todos os lugares importantes e era um sinal da opulência do Grão-Senhor. O luxo, não sem razão, era evocado ao lado do serralho porque o último, tanto quanto o primeiro, eram tomados como símbolos dos vícios tão exaltados pelos membros da política otomana.

Estabelecido na Síria - onde ele afirmava que se podia viajar com uma segurança desconhecida no restante do império -, o autor se propôs a escrever sobre os povos que compunham esse país. Na sua lista, estavam os turcos, os curdos e os árabes. Foi justamente no seu relato sobre os árabes que Volney descreveu o harém, mas sem usar o 
termo. Afirmava ele que "cada tenda habitada por uma família é dividida por uma cortina em duas porções, visto que uma delas pertence somente às mulheres" (VOLNEY, 1787, tomo 1, p. 364). O autor não fez referência aqui a uma suposta lascívia presente entre as mulheres ou entre os homens; tópico muito recorrente nos relatos dos viajantes, como pudemos observar até o momento. O que se nota é, de outro modo, uma distinção entre o erotismo árabe e o turco. Se os árabes podiam ser atrelados às "canções de amor" e a comportamentos castos, os turcos se entregavam ao "deboche", deixando-se levar pelo prazer (p. 374).

O termo serralho também apareceu no Tomo II da obra, mas novamente sem detalhamento por parte do autor. Nesse caso, ele se deteve em explicar que se tratava do "palácio do sultão" (1787, tomo 2, p. 168). Mais adiante, o serralho foi indicado como o "palácio do Príncipe" e descrito como uma "casa grande e pobre, ameaçada de desmoronar-se" (p. 173). Nesse caso, a referência era à cidade de Beirute, no atual Líbano. A palavra serralho foi usada mais uma vez para indicar o palácio de um chefe militar $[A g h a]$ de uma cidade na Palestina, contudo, novamente, sem qualquer detalhamento.

$\mathrm{Na}$ cidade de Ramlah, na Palestina, o autor lembrou que as mulheres - como em todos os lugares do Levante - possuíam uma "moradia separada". Diferentemente dos palácios dos governantes, o que chamava a atenção de Volney a respeito desse lugar era a sua simplicidade. Mais do que isso. No inverno, o apartamento das mulheres parecia o espaço em que ficavam os animais. Somente uma parte da habitação possuía uma elevação de dois pés de 
altura em relação ao abrigo dos animais. A precariedade da vida notada entre esses camponeses - inclusive o espaço de convívio feminino aí estabelecido - pouco despertava o interesse dos viajantes, para quem o luxo dos palácios era um tema de maior relevância. O próprio serralho do Agha de Gaza era descrito como em um estado de ruínas.

$\mathrm{O}$ autor não se interessou em explorar o tema do palácio imperial, tampouco das habitações femininas. A pouca importância dada ao tema do serralho pode ser verificada não apenas no escasso espaço fornecido a ele dentro da narrativa, mas na forma mesma como o termo foi registrado no texto. A palavra serralho foi usada por Volney como sinônimo de palácio e apresentou ao menos três variantes na grafia, se considerarmos também a primeira edição: sérail, seraï e sérâï. Para um autor que havia vivido quase três anos entre o Egito e a Síria e cuja preocupação com a transliteração dos termos estrangeiros havia sido apontada logo no início de seu livro, tal descuido na grafia da palavra serralho não deve ser desprezado. À exceção de uma possível opção tipográfica, isso nos indica o próprio desinteresse do viajante pelo assunto. Além disso, o fato é que os estrangeiros não eram facilmente admitidos no serralho imperial e tampouco nos haréns das casas comuns, o que tornava a descrição de observações empíricas a respeito destes cenários pouco provável. Como alertava o próprio autor, perguntar sobre novidades acerca das mulheres era muito indelicado. Além disso, era preciso ter muita familiaridade para abordar essa matéria.

A dificuldade em tratar o tema não impedia, contudo, que se descrevesse a situação das mulheres dentro do Império Otomano, o que continuava gerando observações e 
reflexões por parte dos europeus. Diferentemente do que escrevera Mary Montagu, Volney declarava que as mulheres pouco participavam da vida social e eram mesmo "isoladas da sociedade dos homens". Em casa, as mulheres ficavam fechadas, podendo manter contato apenas com o seu marido, com o seu pai ou com os seus irmãos. Nas ruas, todas andavam veladas e nenhum homem deveria olhar para elas. Era preciso deixá-las passar, como se tivessem "algo contagioso". Para o autor, os muçulmanos alimentavam um sentimento de desprezo pelas mulheres.

O véu, que servia como uma barreira entre as mulheres islâmicas e os homens estranhos ao seu convívio, também era símbolo dos problemas que assolavam as sociedades do Levante. No caso das comunidades drusas, essa vestimenta era usada pelas mulheres como forma de se protegerem dos homens assolados por paixões exageradas. As paixões intensas também poderiam ser encontradas no baxá de Damasco, que gastava os seus recursos com jardins, banhos e mulheres brancas. De acordo com Volney, este baxá possuía dezoito mulheres em 1784, as quais devoravam o luxo desse governante (VOLNEY, 1787, tomo 2, p. 247).

De todo modo, as explicações usadas por Volney para elucidar a presença da luxúria nas sociedades do Levante não culpabilizavam as mulheres. A responsabilidade sobre a origem de tal situação devia-se às ações da sociedade, as quais eram ordenadas, em última instância, pelo governo tirânico dos otomanos. O autor questionava-se: como as mulheres teriam o pudor necessário para sustentar a virtude, quando elas viam todos os dias cenas ultrajantes de deboche? Como elas teriam uma "moral estimável", 
quando não se tinha qualquer cuidado com a sua educação? (1787, tomo 2, p. 447-448).

Depreende-se disso que Volney apontava a presença das paixões intensas nas sociedades do Levante, contudo, esta premissa não lograva um caráter homogêneo. Além de atribuir ao governo despótico dos otomanos a fonte deste comportamento, o autor não enxergava todas as sociedades islâmicas como iguais. Os turcos certamente exibiam uma prática lasciva que não se verificava a rigor entre os árabes. Descendo mais um grau no seu sistema de pensamento, é preciso lembrar que as mulheres eram vistas como os personagens mais vulneráveis às atitudes nefastas do governo otomano e dos homens em geral. Essa leitura sobre as sociedades islâmicas se devia seguramente ao modo como eram construídas as relações entre os países europeus e tais sociedades. É sobre isto que me deterei agora.

\subsection{0 "outro" na construção da ídentídade europeía}

Como se pôde notar até aqui, as atitudes dos viajantes-escritores em relação ao Levante variavam de uma narrativa para outra. Contudo, ainda que se possa verificar uma marcada simpatia de determinados viajantes pela cultura islâmica, não é possível negar que o "outro" islâmico tenha sido tomado como necessário no processo de construção da identidade europeia ${ }^{49}$. Se neste momento não havia uma guerra religiosa nos moldes das "Cruzadas",

49 No caso do século XIX, Edward Said (1990, p. 283 ss) menciona a metáfora do espelho-imagem, criada por Jacques Waardenburg, em que o Islã era visto como reflexo da própria fraqueza escolhida pelo europeu. 
nem por isso o Islã havia deixado de ser um incômodo para os europeus. Durante o período moderno, não apenas a demarcação entre o cristão e o muçulmano continuava evidente, como um novo ingrediente vinha se somar às relações entre esses grupos: o "perigo turco" se tornava uma ameaça à cristandade (STRÅTH, 2002, p. 391).

De fato, "as interações econômicas e os conflitos militares entre os governantes otomanos e as potências europeias, no Mediterrâneo e nos Bálcãs, não eram em princípio diferentes das correspondentes interações dentro da Europa" (STRÅTH, 2002, p. 392). Ou seja, enquanto alguns países europeus faziam pactos com governantes otomanos, outros faziam guerra. Desse modo, "a fronteira religiosa/étnica construída entre a Europa e o outro Turco tornou-se uma linha europeia fluida de discórdia" (p. 392). Nesse processo de expansão islâmica, os europeus assumiram-se como sinônimos de uma comunidade cristã, a res publica christiana. Durante o século XVII e início do século XVIII, a palavra "cristandade" abriu espaço para o termo "Europa" que emergia como um significante mais neutro e de conotação universal (STRÅTH, 2010, p. 29).

Não sem motivo, nessa época já se poderia encontrar uma tradição descritiva sobre os povos estrangeiros, fossem eles da América, da África ou da Ásia. E não há dúvida de que o conhecimento sobre esses povos - construído a partir de mãos europeias - contribuiu para o avanço da ideia de "Europa". Mesmo que os europeus não tivessem uma consciência explícita disso, as relações mantidas com civilizações desenvolvidas da Ásia ajudaram a consolidar “a percepção de Europa vista em escala global” (KAMEN, 
2000 , p. 2). Não pretendo abordar aqui o extenso percurso que utilizou a experiência do contato com as sociedades estrangeiras no fortalecimento de uma ideia hegemônica de Europa. Mas busco ressaltar, de outro modo, o quanto o século XVII e o século XVIII - encarnado no projeto Iluminista - ajudaram a moldar uma imagem de Europa contraposta, em grande medida, à imagem do que era ser muçulmano.

O processo de construção de uma identidade europeia estendeu-se, na interpretação de Bo Stråth, do século XIV ao século XVIII ${ }^{50}$. Mas o período central da mudança do conceito de comunidade cristã para uma ideia "moderna" de Europa ocorreu entre os fins dos Seiscentos e o início dos Setecentos, "após gerações de conflitos religiosos" (STRÅTH, 2010, p. 29). No século XV, os humanistas tanto empregavam uma retórica clássica para marginalizar os turcos quanto ofereciam visões seculares sobre a cultura e a política islâmicas (FRASSETTO; BLANKS, 1999, p. 198). Portanto, acordos políticos e comerciais entre europeus e muçulmanos não consistiam em impedimento para que aqueles pudessem objetificar a cultura destes. Por haver grupos sociais diferentes do europeu, é que se poderá encontrar em Voltaire, em texto cuja primeira edição data de 1751, a afirmação de que a Europa cristã era uma

espécie de grande república dividida em muitos Estados, uns monárquicos, outros mistos; estes aristocráticos, aqueles populares, mas todos correspondendo

50 Não se trata de uma tese uniforme, por suposto. Há quem defenda que a construção da ideia de Europa teria ocorrido ainda no período medieval. Sobre isso, ver Bartlett, 1993; Frasseto; Blanks, 1999, p. 11-53. 
uns com os outros; todos tendo uma mesma base religiosa, embora divididos em muitas seitas; todos tendo os mesmos princípios de direito público e político, desconhecidos em outras partes do mundo (VOLTAIRE, 1854, p. 6).

Os elementos comuns à Europa citados por Voltaire uniram-se de forma crescente ao interesse pelo cenário político externo. Como lembrou Jonathan Israel, o conflito entre a França e a Inglaterra, a partir de $1689^{51}$, colocava em evidência pela primeira vez uma vasta rivalidade por impérios fora da Europa (2006, p. 609). Nesse processo, não era apenas a "inata superioridade" inglesa sobre os outros europeus que se tornava evidente. A preeminência sobre os povos não brancos, por suposto, era enfática. Fato é que aqui o "Oriente despótico" emergia como contraponto a uma "Europa civilizada" (STRÅTH, 2010, p. 29). Isso não impedia, como apontou o próprio Stråth, que a "construção da Europa", tendo o "outro" como antítese, gerasse, por um lado, sentimentos de superioridade e de admiração pela América e pela Ásia, enquanto que pela África e pela Europa do leste, de outra maneira, o sentimento de superioridade dominasse.

Se no século XVIII a América já era uma região de colonização europeia, o mesmo não ocorria com as sociedades islâmicas. Como ressaltou Edward Said, até o século XIX “o Oriente árabe e islâmico apresentou à Europa um

51 No ano de 1689, a Inglaterra, a Holanda e a Áustria formaram uma coalizão para impedir que a França alargasse as suas fronteiras políticas, abarcando a região de Palatinado [situado atualmente dentro do estado Renânia-Palatinado, a sudoeste da Alemanha]. Sobre essa guerra, ver Johnson, 2011, p. 147. 
desafio não resolvido nos níveis político, intelectual e, por algum tempo, econômico" (1990, p. 115). Daí que encontraremos entre os europeus do século XIX o uso da expressão "civilizações avançadas" para se referirem à China, à Índia, à Pérsia e ao Império Otomano e, ao mesmo tempo, um crescimento sem precedentes em suas incursões imperialistas em territórios islâmicos (WALLERSTEIN, 2007, p. 63-64). Tal postura tinha certamente raízes no período iluminista, no qual os comportamentos teóricos dos europeus em relação às sociedades islâmicas eram ambíguos.

Para refletir sobre as várias sociedades estrangeiras, os iluministas propunham a busca pelo "conhecimento absoluto" que foi seguido pela obsessão em classificar. A classificação, então, dividiria e organizaria hierarquicamente o "mundo empírico" (STRÅTH, 2010, p. 30). Para Londa Schiebinger, o século XVIII foi a "grande era da classificação" (1990, p. 389). Havia, contudo, um problema inicial: como a humanidade seria classificada? A concordância entre muitos anatomistas era de que os corpos humanos poderiam ser diferenciados em idade, sexo e nação. Importante pontuar que o termo "raça" não estava em uso neste momento.

Em relação aos povos muçulmanos, há que se lembrar dos próprios termos usados para identificá-los. Nos séculos XV, XVI e XVII, "atitudes mais tolerantes começam a aparecer" e a palavra "sarracenos" será substituída por "turcos" e "mouros" (FRASSETTO; BLANKS, 1999, p. 2). Ainda que as duas palavras fossem aplicadas para indicar os povos do Império Otomano e do Marrocos, elas eram usadas com mais frequência para significar o "outro" islâmico generalizado (FRASSETTO; BLANKS, 
1999, p. 225). Especialmente em relação à definição do termo "mouro", não era apenas a religião islâmica que servia como premissa. As características físicas também eram aí incorporadas. O sueco Carl Linnaeus (1707-1778), o "principal taxonomista do século dezoito", incluiu o termo "mouros" na categoria de "asiáticos", definindo-o como fuscus, que significa "escuro" (WHEELER, 2000, p. 151).

É possível encontrar a associação entre "mouro" e "pele escura" em outros autores do século XVIII. Denis Diderot (1713-1784) e Jean le Rond d'Alembert (17171783), em artigo da "Enciclopédia" francesa, afirmavam que os povos que viviam entre o Mar Vermelho e o Oceano eram "espécies de Mouros, mas tão morenos que eles parecem quase todos negros". Acrescentavam ainda que os mouros eram misturados com muitos "mulatos" (1765, tomo 8 , p. 346). O naturalista francês Jean-Baptiste Robinet (1735-1820), por sua vez, afirmava que os árabes, persas, egípcios e mouros, vivendo ao sul da zona temperada, eram "bem proporcionados e belos, porém, mais morenos do que os europeus". Isso não o impedia, todavia, de afirmar que as mulheres mouras eram "muito brancas" (ROBINET, 1768 apud THOMSON, 1987, p. 66). Tal observação era possível porque uma teoria recorrente entre os autores Setecentistas era a de que os habitantes do Magrebe [Norte da África] não eram negros e sim "bronzeados pelo sol" (p. 68). Isso explicava o fato de as mulheres reclusas serem brancas. Diante disso, Ann Thomson sustentará que "é raro encontrar no século XVIII afirmações especificamente racistas sobre o Norte da África” (THOMSON, 1987, p. 68). 
A afirmação sobre o excesso de sol a que os mouros estavam submetidos também aparecerá no relato de um viajante inglês. Thomas Shaw (1694-1751), em sua viagem pela "Barbárie" e pelo Levante, sustentava que, embora o termo Mouro usualmente transmitisse a "ideia de uma pessoa de compleição negra ou morena”, esta palavra denotava somente a "situação do seu país" (SHAW, 1757, p. 241). O que ocorria é que os mouros ficavam muito expostos ao sol, o que determinava a sua cor morena tanto quanto o tom de pele dos árabes (p. 241). A postura mudava, entretanto, quando o autor buscava descrever os árabes ou os "Árabes selvagens”, como ele nomeava. Para o viajante, os árabes eram todos iguais e possuíam as mesmas inclinações: o roubo, o despojo e o assassinato, visto que isso se verificava não apenas em relação aos estrangeiros, mas também entre eles (p. $\mathrm{x}$ ).

Um dos instrumentos usados pelos europeus para representar os "árabes selvagens" ou as práticas piratas dos mouros era a literatura sobre cativos. O gênero de cativeiro se referia ao crescente número de viajantes europeus aprisionados na costa norte-africana. Aqueles que conseguiam escapar não raro relatavam a sua dramática experiência em forma de texto. O próprio autor citado no primeiro capítulo, T.S., descrevia os seus anos de prisão no Magrebe. Como ressalta Joe Snader, “árabes, berberes, mouros, turcos, judeus, africanos e escravos dos Bálcãs, mesmo um número de 'renegados', ou ocidentais convertidos ao Islã", tendiam a ser agrupados pelos viajantes ingleses sob a rubrica de "turcos" ou "mouros". O retrato desses grupos, de forma geral, era a sua inclinação à "tirania, à crueldade, à luxúria, à ardileza, à paixão imoderada 
e à superstição" (SNADER, 2000, p. 132-133). Dado o caráter supostamente inferior desses grupos, o cativeiro dos europeus gerava uma "violação da hierarquia nacional imaginada que colocava as culturas ocidentais acima das não ocidentais” (p. 63).

O sentimento de superioridade em relação a outro grupo do Levante exibia-se mesclado a um ar de admiração. Em 1653, o viajante François de La Boullaye-Le Gouz exaltava a índole dos persas, afirmando que eles permitiam que se falasse sobre religião - tanto aos nativos quanto aos estrangeiros - e confessavam de "boa fé a perda de uma batalha ou de uma cidade" (1653, p. 111-112). Portanto, os persas tinham "muito da natureza dos franceses” (p. 111-112). A aproximação entre persas e franceses também seria ressaltada pelo filósofo alemão Immanuel Kant (1724-1804), na obra "Observações sobre o sentimento do belo e do sublime", de 1764. Os persas eram tomados como os "franceses da Ásia”, porque eram "bons poetas, corteses e de bom gosto" (KANT, 1764 apud EZE, 1997, p. 54-55). Este povo era visto ainda como dotado de "características messiânicas" (BRENTJES, 1999, p. 450). Diferentemente dos mouros, os persas possuíam traços dignos de destaque, como o fato de ser o "povo mais civilizado do Oriente" na interpretação do joalheiro e viajante Jean Chardin (1686, tomo 4, p. 108).

A ligação da Pérsia com a Europa como um todo foi defendida por outros autores para além de uma semelhança moral. René Grousset, na metade do século passado, sustentava que o Irã era "essencialmente indo-europeu". O "pensamento iraniano" não se aparentava às "velhas concepções babilônicas", mas sim à "mais alta” especulação indiana e 
ao pensamento grego "mais espiritualizado" (GROUSSET, 1955 apud HENTSCH, 1988, p. 21-22). Se uma suposta divisão da Ásia entre os semitas e os indo-europeus permitia uma maior identificação dos europeus com os persas, o mesmo não ocorria em relação aos turcos.

Os turcos eram o grupo por excelência que mais incomodava os europeus no início da modernidade e que, por conseguinte, mais contribuiu para a discussão sobre a identidade europeia nesse período. O seu poder militar, a sua proximidade física e a sua forte tradição religiosa os colocaram em uma posição central dentro do processo de construção das identidades europeias (NEUMANN, 1999, p. 40). Assim como "o sarraceno" havia estado presente na criação da Europa Carolíngia, o "turco otomano" estaria presente na criação do sistema de Estado Moderno europeu. Não sem razão, foi durante o período de crescimento do Império Otomano - processo que envolveu a tomada de Constantinopla, em 1453 - que o termo "Europa" começou a ser frequentemente usado e assumiu uma importância política. Curiosamente, ele era o termo predileto do papa Pio II (1405-1464) que o empregou pela primeira vez no título de um livro (p. 44).

A conquista de Constantinopla pelos otomanos ainda que fosse vista como resultado das dissensões entre os cristãos - foi usada para ressaltar o senso coletivo europeu. Contra o inimigo externo, o discurso de unidade cristã reacendeu-se na Europa, relembrando as "Cruzadas" medievais. A resposta religiosa ao poderio militar otomano pode ser encontrada nas palavras do papa Pio II que propunha aos europeus pegarem em armas e irem à guerra contra "o inimigo" (NEUMANN, 1999, p. 45). 
Ao lado das ações religiosas, havia seguramente um apelo a argumentos práticos que indicava o quão ameaçador era o avanço otomano em relação aos interesses dos governantes europeus. Porém, como afirma Maxime Rodinson, estes não estavam convencidos de que o expansionismo cristão merecesse o sacrifício de seus próprios interesses políticos - ou eventualmente nacionais. Além disso, o poderio militar islâmico estava dentro da Europa, o que tornava as relações políticas com os otomanos imprescindíveis (RODINSON, 2006, p. 33).

Esta necessidade de relacionamento diplomático com os turcos não impediu por suposto que os europeus continuassem a encará-los como inimigos. O que se observa, nesse sentido, é que até à morte do sultão Mehmet II, em 1481, alianças contra o Império Otomano revelaram-se como a mais proeminente característica das relações internacionais europeias. Por outro lado, passou a haver um significativo envolvimento dos otomanos nos conflitos europeus. A primeira aliança entre otomanos e europeus ocorreu em 1536, quando Francisco I da França assinou com eles um tratado contra os Estados italianos. A partir de então, a cooperação passaria a caracterizar as relações entre turcos e franceses (NEUMANN, 1999, p. 47-48). Portanto, como aponta Iver Neumann, "as potências europeias aprenderam rapidamente a fazer negócios com 'o turco', incluindo-o em suas maquinações diplomáticas” (p. 47).

Se "o turco" podia ser contraposto ao europeu é porque no tocante à religião este era cristão e o "Cristianismo era frequentemente contrastado com o Islã dos Impérios Otomano e Mogol, com o Hinduísmo da Índia e com a tradição Confucionista da China imperial" (PURNELL, 
1973 apud NEUMANN, 1999, p. 50). Somada à religião, outra instância que promovia a diferença - e criava um sentimento de temor - entre os turcos e os europeus era a superioridade militar daqueles. Contudo, a "Batalha de Viena", ocorrida em 1683, marcaria o fim das investidas otomanas na Europa central, levando inclusive à assinatura do "Tratado de Karlowitz", em 1699. Esse tratado indicava não apenas a superioridade militar europeia, como também obrigava o Império Otomano a reconhecer, pela primeira vez, a existência formal de Estados não muçulmanos (NEUMANN, p. 51-52).

Se a ameaça militar mostrava-se arrefecida, a "ameaça cultural" turca crescia em importância. Dentro desse cenário, os relatos de viagem ganhavam destaque, uma vez que poderiam registrar empiricamente as características das sociedades que compunham o Império Otomano. Neumann nota que o crescente emprego do termo grego "bárbaro" é um indicativo de como o sistema de estado secular suplantava a religião em uma diferenciação entre a Europa e as comunidades não europeias. Para este autor, o que ganhava força era "um conjunto de 'relações interculturais' entre a Europa e 'o Turco'”, o que promovia "uma distinção nítida entre a civilização e a barbárie" (NEUMANN, 1999, p. 52).

Não há dúvida de que o uso desse termo se justificava, em grande medida, pela forma como os europeus enxergavam o governo dos otomanos. O uso da palavra "despotismo" e da expressão "despotismo oriental" para caracterizar "os sistemas político e social na Ásia, especialmente no Oriente Médio, tornou-se habitual em meados do século XVIII" (KONRAD, 2011). O taxonomista Carl 
Linnaeus, citado anteriormente, sustentava que os asiáticos eram governados mais por opiniões do que por uma forma racional de governo (WHEELER, 2000, p. 152). Sobre isso, há que se lembrar da teoria sobre o despotismo asiático construída por Montesquieu, na qual o autor defendia o despotismo como uma forma de governo característica da Ásia. Voltarei a este tópico no Capítulo 5. Para tanto, o autor se baseava de forma ampla em autores de viagem (KONRAD, 2011). É também em relatos de viagem - nesse caso, de diplomatas venezianos - que Felix Konrad afirma existir, até aproximadamente o ano de 1575, "certo fascínio ou admiração pelo reino do Sultão, embora este fascínio fosse sempre combinado com aversão". Isso teria mudado radicalmente após esta data. A partir de então, os otomanos passariam a ser vistos como o oposto dos venezianos e o seu império seria tratado como a "maior tirania da história" (VALENSI, 1990 apud KONRAD, 2011).

A partir desse cenário, a identidade e o caráter de superioridade entre os europeus se tornavam mais aprofundados. No século XVIII, portanto, será bastante comum encontrar autores que enxergavam na Europa uma "sociedade de nações e estados", como o advogado G. F. Martens, em 1795. Dando um passo adiante, havia vozes que defendiam a Europa como "um tipo de república", como o filósofo suíço Emmerich de Vattel, o abade francês Dominique-Georges-Frederic de Pradt ou mesmo o já citado Voltaire (NEUMANN, 1999, p. 52). Em um panorama de declínio político e militar otomano, após o fracasso na "Batalha de Viena", um apreço pela "moda turca" ou turqueria passava a ser notado entre os europeus, 
especialmente entre os franceses. Sobre isso, Konrad cita a publicação de uma "biografia objetiva sobre o profeta", assim como do Livro das Mil e Uma Noites por Antoine Galland e até mesmo a afirmação de "muitos intelectuais" iluministas de que o Islã era uma religião tolerante (KONRAD, 2011).

Essas práticas, contudo, não resultaram na eliminação completa de velhos padrões de pensamento. O profeta Muhammad continuava a ser visto como um "impostor e fanático" - nesse caso, na obra de Voltaire ${ }^{52}$ - e a suposta admiração europeia pelos turcos não raro declinava em grosseiras representações sobre o "outro". Não sem razão, Mustafa Soykut enxerga no período das Luzes o nascimento do "Orientalismo" no sentido moderno do termo (2001, p. 111). Nessa busca por conhecer o muçulmano, os autores não se furtaram em discorrer, em menor ou em maior grau, sobre o harém. É, portanto, o cruzamento das observações sobre o harém esboçadas até aqui que buscarei explorar no próximo capítulo.

${ }_{52} \mathrm{Na}$ obra Mahomet ou le fanatisme, o profeta era retratado como um "impostor cuja ambição política o levou a se servir das forças da religião para submeter o mundo e os homens" (BOULAD-AYOUB, 1990, p. 12). 